\title{
Long-term trends in air quality in major cities in the UK and India: a view from space
}

\author{
Karn Vohra ${ }^{1}$, Eloise A. Marais ${ }^{2, a}$, Shannen Suckra ${ }^{1, b}$, Louisa Kramer ${ }^{1, c}$, William J. Bloss ${ }^{1}$, Ravi Sahu ${ }^{3}$, \\ Abhishek Gaur ${ }^{3}$, Sachchida N. Tripathi ${ }^{3}$, Martin Van Damme ${ }^{4}$, Lieven Clarisse ${ }^{4}$, and Pierre-F. Coheur ${ }^{4}$ \\ ${ }^{1}$ School of Geography, Earth and Environmental Sciences, University of Birmingham, Birmingham, UK \\ ${ }^{2}$ School of Physics and Astronomy, University of Leicester, Leicester, UK \\ ${ }^{3}$ Department of Civil Engineering, Indian Institute of Technology Kanpur, Kanpur, India \\ ${ }^{4}$ Université libre de Bruxelles (ULB), Spectroscopy, Quantum Chemistry and Atmospheric Remote Sensing (SQUARES), \\ Brussels, Belgium \\ ${ }^{a}$ now at: Department of Geography, University of College London, London, UK \\ ${ }^{\mathrm{b}}$ now at: National Environment \& Planning Agency, Kingston, Jamaica \\ ${ }^{\mathrm{c}}$ now at: Ricardo Energy \& Environment, Harwell, UK
}

Correspondence: Eloise A. Marais (e.marais@ucl.ac.uk)

Received: 8 April 2020 - Discussion started: 26 August 2020

Revised: 11 March 2021 - Accepted: 12 March 2021 - Published: 29 April 2021

\begin{abstract}
Air quality networks in cities can be costly and inconsistent and typically monitor a few pollutants. Spacebased instruments provide global coverage spanning more than a decade to determine trends in air quality, augmenting surface networks. Here we target cities in the UK (London and Birmingham) and India (Delhi and Kanpur) and use observations of nitrogen dioxide $\left(\mathrm{NO}_{2}\right)$ from the Ozone Monitoring Instrument (OMI), ammonia $\left(\mathrm{NH}_{3}\right)$ from the Infrared Atmospheric Sounding Interferometer (IASI), formaldehyde (HCHO) from OMI as a proxy for non-methane volatile organic compounds (NMVOCs), and aerosol optical depth (AOD) from the Moderate Resolution Imaging Spectroradiometer (MODIS) for $\mathrm{PM}_{2.5}$. We assess the skill of these products at reproducing monthly variability in surface concentrations of air pollutants where available. We find temporal consistency between column and surface $\mathrm{NO}_{2}$ in cities in the UK and India $(R=0.5-0.7)$ and $\mathrm{NH}_{3}$ at two of three rural sites in the UK $(R=0.5-0.7)$ but not between AOD and surface $\mathrm{PM}_{2.5}(R<0.4)$. MODIS AOD is consistent with AERONET at sites in the UK and India $(R \geq 0.8)$ and reproduces a significant decline in surface $\mathrm{PM}_{2.5}$ in London $\left(2.7 \% \mathrm{a}^{-1}\right)$ and Birmingham $\left(3.7 \% \mathrm{a}^{-1}\right)$ since 2009 . We derive long-term trends in the four cities for 2005-2018 from OMI and MODIS and for 2008-2018 from IASI. Trends of all pollutants are positive in Delhi, suggesting no air quality
\end{abstract}

improvements there, despite the roll-out of controls on industrial and transport sectors. Kanpur, identified by the WHO as the most polluted city in the world in 2018, experiences a significant and substantial $\left(3.1 \% \mathrm{a}^{-1}\right)$ increase in $\mathrm{PM}_{2.5}$. The decline of $\mathrm{NO}_{2}, \mathrm{NH}_{3}$, and $\mathrm{PM}_{2.5}$ in London and Birmingham is likely due in large part to emissions controls on vehicles. Trends are significant only for $\mathrm{NO}_{2}$ and $\mathrm{PM}_{2.5}$. Reactive NMVOCs decline in Birmingham, but the trend is not significant. There is a recent (2012-2018) steep $\left(>9 \% \mathrm{a}^{-1}\right)$ increase in reactive NMVOCs in London. The cause for this rapid increase is uncertain but may reflect the increased contribution of oxygenated volatile organic compounds (VOCs) from household products, the food and beverage industry, and domestic wood burning, with implications for the formation of ozone in a VOC-limited city.

\section{Introduction}

More than $55 \%$ of people live in urban areas, and this is projected to increase to $68 \%$ by 2050 (UN, 2019). Air pollution in cities routinely exceeds levels safe for human health (Landrigan et al., 2018). Regulatory air quality monitoring networks, such as those employed in cities in the UK and India, provide detailed data concerning individual species and spe- 
cific locations but are labour-intensive to operate and maintain, with potential gaps in spatial coverage and discontinuities hindering longer term trend discovery. Here we assess the ability to use the long record of satellite observations of atmospheric composition to monitor long-term trends in surface air quality in cities in the UK (London, Birmingham) and India (Delhi, Kanpur) of variable size, at a range of development stages, and with air pollutant concentrations that pose a greater risk to health than previously thought (Vodonos et al., 2018; Vohra et al., 2021).

Our study focuses on two large cities in the UK (London and Birmingham) and two in India (Delhi and Kanpur). Each is at a different stage of development: London is well developed, Birmingham is undergoing urban renewal, Delhi is experiencing rapid development (Singh and Grover, 2015), and Kanpur is a rapidly industrialising city (World Bank, 2014). Air quality policy is well established in the UK, and the rapid decline in regulated air pollutants and their precursors has been monitored since 1970. According to the National Atmospheric Emission Inventory (NAEI), precursor emissions of fine particles with aerodynamic diameter $<2.5 \mu \mathrm{m}$ $\left(\mathrm{PM}_{2.5}\right)$ decreased in $1970-2017$ by $1.5 \% \mathrm{a}^{-1}$ for nitrogen oxides $\left(\mathrm{NO}_{x} \equiv \mathrm{NO}+\mathrm{NO}_{2}\right), 2.0 \% \mathrm{a}^{-1}$ for sulfur dioxide $\left(\mathrm{SO}_{2}\right)$, and $1.4 \% \mathrm{a}^{-1}$ for non-methane volatile organic compounds (NMVOCs). Primary $\mathrm{PM}_{2.5}$ emissions decreased by $1.6 \% \mathrm{a}^{-1}$ over the same time period compared to a decline of just $0.2 \% \mathrm{a}^{-1}$ for ammonia $\left(\mathrm{NH}_{3}\right)$ emissions during 1980 2017 (Defra, 2019a). In UK cities, vehicles make a large contribution to air pollution year-round, with seasonal contributions from residential fuelwood burning, agricultural activity, and construction and sporadic contributions from the longrange transport of Saharan dust (Fuller et al., 2014; Crilley et al., 2015; 2017; Harrison et al., 2018; Ots et al., 2018; Carnell et al., 2019). Despite the decline in emissions, many areas in the UK still exceed the legal annual mean limit of $\mathrm{NO}_{2}$ of $40 \mathrm{\mu g} \mathrm{m}^{-3}$ (Barnes et al., 2018), a threshold that may not adequately protect against the health effects of long-term exposure to $\mathrm{NO}_{2}$ (Lyons et al., 2020). Many areas will also exceed the annual mean $\mathrm{PM}_{2.5}$ standard, if updated from 25 to $10 \mu \mathrm{g} \mathrm{m}^{-3}$, according to the WHO guideline (Defra, 2019b). Reported annual mean $\mathrm{PM}_{2.5}$ in 2016, obtained as the surface monitoring network average, is $12 \mu \mathrm{g} \mathrm{m}^{-3}$ for London and $10 \mathrm{\mu g} \mathrm{m}^{-3}$ for Birmingham (WHO, 2018). There is increasing concern over emissions of the important $\mathrm{PM}_{2.5}$ precursor, $\mathrm{NH}_{3}$, as there are no direct controls on the agricultural sector, the dominant $\mathrm{NH}_{3}$ source (Carnell et al., 2019). There has even been a recent increase in $\mathrm{NH}_{3}$ emissions of $1.9 \% \mathrm{a}^{-1}$ in 2013-2017 (Defra, 2019a), attributed to agriculture (Carnell et al., 2019).

Air quality policy in India is in its infancy compared to the UK. The first air pollution act was passed in 1981, 30 years after the equivalent in the UK. There has been a steady roll-out of European-style (Euro VI) vehicle emission standards, starting with Delhi in 2018 and scaling up to the whole country by 2020 (Govt. of India, 2016). Strict controls on coal-fired power plants have been in place since December 2015, but most power plants are non-compliant (Sugathan et al., 2018). National $\mathrm{PM}_{2.5}$ concentration targets have been set at $20 \%-30 \%$ reductions by 2024 relative to 2017 levels (Govt. of India, 2019), but in 2016, measured annual mean $\mathrm{PM}_{2.5}$ in Delhi and Kanpur exceeded the national standard $\left(40 \mu \mathrm{g} \mathrm{m}^{-3}\right)$ by about a factor of $4: 143 \mu \mathrm{g} \mathrm{m}^{-3}$ for Delhi and $173 \mu \mathrm{g} \mathrm{m}^{-3}$ for Kanpur (WHO, 2018). In Delhi and Kanpur, year-round emissions are dominated by vehicles, construction, and household biofuel use in the city and industrial activity and coal combustion nearby (Guttikunda and Jawahar, 2014; Venkataraman et al., 2018). Seasonal enhancements come from intense agricultural fires along the Indo-Gangetic Plain (IGP) north of Delhi, frequent firework festivals, and dust storms originating from the Thar Desert and Arabian Peninsula (Ghosh et al., 2014; Parkhi et al., 2016; Yadav et al., 2017; Cusworth et al., 2018; Liu et al., 2018). Like the UK, the agricultural sector is not directly regulated, and intense agricultural activity in the IGP contributes to the largest global $\mathrm{NH}_{3}$ hotspot (Warner et al., 2017; Van Damme et al., 2018; T. Wang et al., 2020).

Surface monitoring networks in cities in the UK and India needed to evaluate citywide trends in air pollutant concentrations and precursor emissions can be exceedingly sparse and are often short-term. To illustrate this, we show in Fig. 1 the coverage of surface sites in the four cities that continuously monitor $\mathrm{NO}_{2}$, the most widely monitored air pollutant in both countries. There are also diffusion tubes and emerging technologies that measure $\mathrm{NO}_{2}$ at low cost, but these are susceptible to biases (Heal et al., 1999; Castell et al., 2017) and so are excluded. The points in Fig. 1 show sites established and maintained by national agencies, local city councils, and academic institutions. These are coloured by multi-year mean $\mathrm{NO}_{2}$ around the satellite midday overpass (12:00-15:00 local time or LT) for our period of interest (2005-2018). London has the most extensive surface coverage. There can be more than 100 sites operating simultaneously, but many of these are short-term. Most long-term sites are in central London, and southeast London is devoid of stations. Birmingham has eight monitoring stations, but only two operated for the majority of 2005-2018. There are recently established comprehensive air quality monitoring sites in London and Birmingham, but these started operating in late 2018. More than $40 \%$ of the $\mathrm{NO}_{2}$ monitoring stations in Delhi were established in 2018, and there are concerns over data access and quality (Cusworth et al., 2018). Fewer stations in the four cities monitor $\mathrm{PM}_{2.5}$ than $\mathrm{NO}_{2}$, and measurements of NMVOCs are limited to a few short-term intensive campaigns and longterm sites that only measure light (short-chain) non-methane hydrocarbons. Long-term continuous monitoring of $\mathrm{NH}_{3}$ in the UK is limited to hourly measurements at rural European Monitoring and Evaluation Programme (EMEP) sites (Fig. 1) and monthly measurements at UK Eutrophying and Acidifying Pollutants (UKEAP) network sites. 
UK

(a)

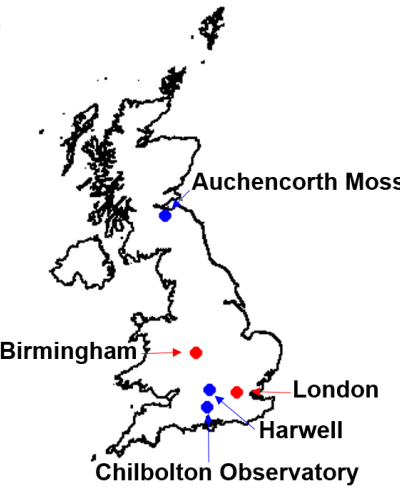

London $\left(1572 \mathrm{~km}^{2}\right)$

(b)

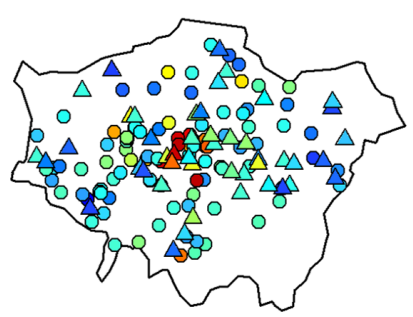

Birmingham (268 km²)

(c)

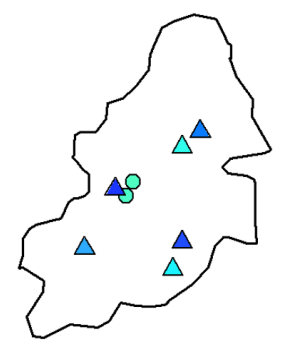

India

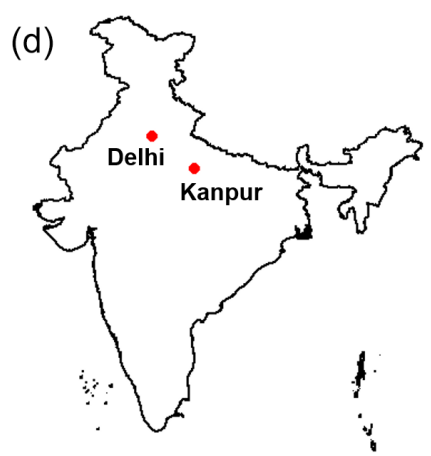

Delhi $(1484$ km²)

(e)

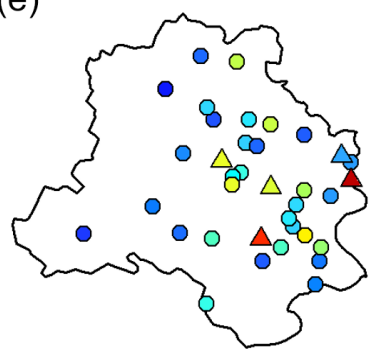

(f)

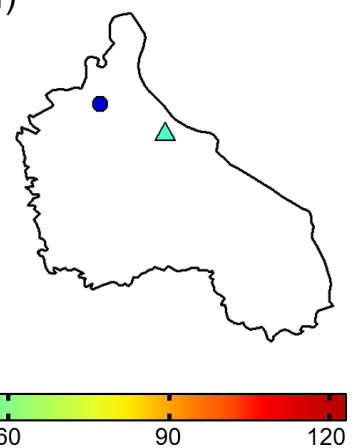

Figure 1. Spatial extent of surface $\mathrm{NO}_{2}$ monitoring stations in London (b), Birmingham (c), Delhi (e), and Kanpur (f). Panels (a) and (d) show the location of the target cities (red) and UK sites that are part of the European Monitoring and Evaluation Programme (EMEP) (blue). Panels (b), (c), (e), and (f) show the locations of local authority regulatory $\mathrm{NO}_{2}$ monitoring stations within the administrative boundaries of each city, coloured by mean midday $\mathrm{NO}_{2}$ for 2005-2018 and separated into sites used (triangles) and not used (circles) to assess satellite observations of $\mathrm{NO}_{2}$ (see text for details). The surface area of each city is indicated. Country and city boundaries are from GADM version 3.6 (GADM, 2018) and DataMeet (DataMeet, 2018).

Satellite observations of atmospheric composition (Earth observations) provide consistent, long records (>10 years) and global coverage of multiple air pollutants, complementing surface monitoring networks with limited spatial coverage and temporal records (Streets et al., 2013; Duncan et al., 2014). These have been used extensively as constraints on temporal changes in surface concentrations of air pollutants and precursor emissions (Kim et al., 2006; Lamsal et al., 2011; Zhu et al., 2014) but typically just targeting one-two pollutants. In this work, we consider Earth observations of $\mathrm{NO}_{2}$, formaldehyde ( $\mathrm{HCHO}$ ), $\mathrm{NH}_{3}$, and aerosol optical depth (AOD). HCHO is a prompt, high-yield, ubiquitous oxidation product of NMVOCs used as a constraint on NMVOCs emissions (Miller et al., 2008; De Smedt et al., 2010; Marais et al., 2012, 2014a, b). AOD has been used to derive surface concentrations of $\mathrm{PM}_{2.5}$ for the global assessment of the impact of air pollution on health (van Donkelaar et al., 2006, 2010, Brauer et al., 2016; Anenberg et al., 2019).

Here we conduct a systematic evaluation of the ability of satellite observations of $\mathrm{NO}_{2}, \mathrm{NH}_{3}, \mathrm{HCHO}$, and AOD to re- produce the temporal variability of surface air pollution in the UK and India before going on to apply these satellite observations to estimate long-term changes in air pollution to assess the efficacy of air quality policies in the four cities of interest.

\section{Space-based and surface air quality observations}

Earth observations of $\mathrm{NO}_{2}$ and $\mathrm{HCHO}$ are from the Ozone Monitoring Instrument (OMI), $\mathrm{NH}_{3}$ from the Infrared Atmospheric Sounding Interferometer (IASI), and AOD from the Moderate Resolution Imaging Spectroradiometer (MODIS). There are also observations of $\mathrm{SO}_{2}$ and the secondary pollutant ozone from OMI, but $\mathrm{SO}_{2}$ is below or close to the detection limit year-round for all cities, except in some months in Delhi, and UV measurements of tropospheric column ozone have limited sensitivity to ozone in the boundary layer (Zoogman et al., 2011). TROPOspheric Monitoring Instrument (TROPOMI) sensitivity to $\mathrm{SO}_{2}$ is 4 -fold bet- 
ter than OMI, but the observation record is short (October 2017 launch) (Theys et al., 2019). We use hourly observations of $\mathrm{NO}_{2}$ and $\mathrm{PM}_{2.5}$ from the network of surface sites in the four target cities and $\mathrm{NH}_{3}$ from the rural EMEP sites in the UK, to assess whether satellite observations of $\mathrm{NO}_{2}$, AOD, and $\mathrm{NH}_{3}$ reproduce temporal variability of surface air quality. There are no direct reliable measurements of $\mathrm{HCHO}$ in the UK, and measurements of NMVOCs are limited to a few sites that only measure light $(\leq \mathrm{C} 9)$ hydrocarbons.

Figure 1 shows locations of EMEP sites in Harwell, England, south of Oxford $\left(51.57^{\circ} \mathrm{N}, 1.32^{\circ} \mathrm{W}\right)$, Chilbolton Observatory, England, $65 \mathrm{~km}$ south of Harwell $\left(51.15^{\circ} \mathrm{N}\right.$, $1.44^{\circ} \mathrm{W}$ ), and Auchencorth Moss, Scotland, south of Edinburgh $\left(55.79^{\circ} \mathrm{N}, 3.24^{\circ} \mathrm{W}\right.$ ) (Malley et al., 2015, 2016; Walker et al., 2019). Instruments at the Harwell site were relocated to Chilbolton Observatory in 2016, providing the opportunity to assess the satellite data at sites with distinct agricultural activity and anthropogenic influence (Walker et al., 2019). There are also passive $\mathrm{NH}_{3}$ samplers in the UK, but these have coarse temporal (monthly) resolution (Tang et al., 2018) and no temporal correlation $(R<0.1)$ with a previous version of the IASI $\mathrm{NH}_{3}$ product (Van Damme et al., 2015).

\subsection{Surface monitoring networks in the UK and India}

Surface sites in the UK with continuous (hourly) observations of air pollutants typically use chemiluminescence instruments for $\mathrm{NO}_{2}$, ion chromatography instruments for $\mathrm{NH}_{3}$ (Stieger et al., 2018), and a range of reference instruments for $\mathrm{PM}_{10}$ and $\mathrm{PM}_{2.5}$. Sites used here in London and Birmingham are from the national Department for Environment, Food and Rural Affairs (Defra) Automatic Urban and Rural Network (AURN) (https://uk-air.defra.gov. uk/data/data_selector; last access: 28 January 2020) with additional sites in London from the King's College London Air Quality Network (LAQN) (https://www.londonair. org.uk/london/asp/datadownload.asp; last access: 9 March 2019) and in Birmingham from Ricardo Energy \& Environment (https://www.airqualityengland.co.uk/local-authority/ data?la_id=407; last access: 24 January 2020) and Birmingham City Council. Observations at the UK EMEP sites are from the EMEP Chemical Coordinating Centre (http: //ebas.nilu.no/; last access: 9 March 2019). Measurements in India are limited to $\mathrm{NO}_{2}, \mathrm{PM}_{10}$, and $\mathrm{PM}_{2.5}$ monitoring sites maintained in Delhi by the Central Pollution Control Board (CPCB), India Meteorological Department (IMD), and Delhi Pollution Control Committee (DPCC) and in Kanpur by the Uttar Pradesh Pollution Control Board (UPPCB) and the Indian Institute of Technology (IIT) Kanpur (Gaur et al., 2014). $\mathrm{PM}_{2.5}$ measurements at IIT Kanpur form part of the international Surface Particulate Matter Network (SPARTAN) (Snider et al., 2015; Weagle et al., 2018). Data from CPCB, IMD, DPCC, and UPPCB were downloaded from the CPCB site (https://app.cpcbccr.com/ ccr/\#/caaqm-dashboard/caaqm-landing; last access: 5 Febru- ary 2020). NASA AErosol RObotic NETwork (AERONET) sun photometer AOD measurements (version 3.0, Level 2.0; https://aeronet.gsfc.nasa.gov/; last access: 5 February 2020) are used to validate MODIS AOD at Chilbolton (UK) and Kanpur (India) (Holben et al., 1998; Giles et al., 2019).

\subsection{Earth observations of air pollution}

OMI on board the NASA Aura satellite, launched in October 2004 , has a nadir spatial resolution of $13 \mathrm{~km} \times 24 \mathrm{~km}$ and a swath width of $2600 \mathrm{~km}$ and passes overhead twice each day. OMI is a UV-visible spectrometer and so only provides daytime observations (13:30 LT). Global coverage was daily in 2005-2009 and is every $2 \mathrm{~d}$ thereafter due to the row anomaly (http://omi.fmi.fi/anomaly.html, last access: 8 March 2020). We use the operational NASA OMI Level 2 product of tropospheric column $\mathrm{NO}_{2}$ for 2005-2018 (version 3.0; https://doi.org/10.5067/Aura/OMI/DATA2017; last access: 29 February 2020) (Krotkov et al., 2017). Total columns of $\mathrm{HCHO}$ are from the Quality Assurance for Essential Climate Variables (QA4ECV) OMI Level 2 product for 20052018 (version 1.1; https://doi.org/10.18758/71021031; last access: 15 February 2020) (De Smedt et al., 2018). We remove $\mathrm{OMI} \mathrm{NO} \mathrm{N}_{2}$ scenes with cloud radiance fraction $\geq 50 \%$, terrain reflectivity $\geq 30 \%$, and solar zenith angle (SZA) $\geq$ $85^{\circ}$ (Lamsal et al., 2010) and OMI HCHO scenes with processing errors and processing quality flags not equal to zero (De Smedt et al., 2017). This removes scenes with cloud radiance fraction $>60 \%$ and $\mathrm{SZA}>80^{\circ}$. We apply additional filtering to remove scenes with cloud radiance fraction $\geq 50 \%$ to be consistent with the threshold applied to OMI $\mathrm{NO}_{2}$. This additional filtering removes $16 \%$ of the data for London, $19 \%$ for Birmingham, $7 \%$ for Delhi, and $8 \%$ for Kanpur.

IASI on the polar sun-synchronous Metop-A satellite, launched in October 2006, is an infrared instrument with a morning (09:30 LT) and nighttime (21:30 LT) overpass. It provides global coverage twice a day with circular $12 \mathrm{~km}$ diameter pixels at nadir and a swath width of $2200 \mathrm{~km}$. We use observations for the morning only, when the thermal contrast and sensitivity to the boundary layer are greatest (Clarisse et al., 2010; Van Damme et al., 2014). We use the Level 2 reanalysis product of total column $\mathrm{NH}_{3}$ (version $3 \mathrm{R}$ ) obtained with consistent meteorology (ERA5) for clear-sky conditions (cloud fraction $<10 \%$ ) (Van Damme et al., 2020). The earlier IASI $\mathrm{NH}_{3}$ product version (version $2 \mathrm{R}$ ) was shown to be consistent with ground-based measurements of total column $\mathrm{NH}_{3}$ at nine global sites (Dammers et al., 2016).

The MODIS sensor on board NASA's Aqua satellite, launched in May 2002, has a swath width of $2330 \mathrm{~km}$, crosses the Equator at 13:30 LT, and provides near-daily global coverage. We use the Level 2 Collection 6.1 Dark Target daily AOD product at $550 \mathrm{~nm}$ and $3 \mathrm{~km}$ resolution (Remer et al., 2013; Wei et al., 2019) (https://ladsweb.modaps.eosdis.nasa. gov/; last access: 29 February 2020). We use only the highest 
quality AOD data (quality assurance flag of 3) (Munchak et al., 2013; Remer et al., 2013; Gupta et al., 2018).

\section{Consistency between Earth observations and surface air pollution}

Earth observation products retrieve column densities of pollutants throughout the atmospheric column (total for HCHO, AOD and $\mathrm{NH}_{3}$; troposphere for $\mathrm{NO}_{2}$ ) and are compared in what follows to surface concentrations from the surface monitoring network sites. This is to evaluate whether monthly variability in the column reproduces variability in surface concentrations before going on to use the satellite observations to quantify long-term trends in air pollution in the four cities. The majority of the enhancement in the column, with the exception of events like long-range transport, is near the surface (Fishman et al., 2008; Duncan et al., 2014). Sources of errors in retrieval of $\mathrm{HCHO}$ and $\mathrm{NO}_{2}$ column densities include uncertainties in simulated vertical profiles and the presence of clouds and aerosols (Boersma et al., 2004; Lin et al., 2015; Zhu et al., 2016; Silvern et al., 2018). Retrieval of $\mathrm{NH}_{3}$ column densities from IASI relies on thermal contrast between the Earth's surface and atmosphere and a sufficiently large training dataset (Whitburn et al., 2016; Van Damme et al., 2017). Errors in retrieval of AOD include uncertainties in aerosol properties and atmospheric conditions in matching simulated and observed top-of-atmosphere radiances from single viewing angle instruments like MODIS (Remer et al., 2005; Levy et al., 2007, 2013). To the extent that errors are random, these are reduced with temporal and spatial averaging.

In what follows, city-average $\mathrm{OMI} \mathrm{NO}_{2}$ and MODIS AOD are compared to representative city-average surface concentrations of $\mathrm{NO}_{2}$ in all four cities and $\mathrm{PM}_{2.5}$ in London and Birmingham. IASI $\mathrm{NH}_{3}$ is compared to coincident surface observations of $\mathrm{NH}_{3}$ at UK EMEP sites (Fig. 1).

\subsection{Assessment of $\mathrm{OMI} \mathrm{NO}_{2}$}

Data for $\mathrm{NO}_{2}$ in the UK include 152 monitoring sites in London, 8 in Birmingham, 37 in Delhi, and 2 in Kanpur (Fig. 1). The data we use for London and Birmingham have been independently ratified, but we still find and remove spurious $\mathrm{NO}_{2}$ observations. These include persistent $(>24 \mathrm{~h})$ low $\left(<1 \mu \mathrm{g} \mathrm{m}^{-3}\right)$ values that do not exhibit diurnal variability. This occurs at fewer than $10 \%$ of the sites and accounts for at most $1 \%$ of the data at these sites. We identified that $\mathrm{NO}_{2}$ data from DPCC and CPCB (Delhi) and from UPPCB (Kanpur) networks are inconsistently reported in either parts per billion by volume (ppbv) or micrograms per cubic metre $\left(\mu \mathrm{g} \mathrm{m}^{-3}\right)$. As information on the units of the individual data is not provided, we determine whether $\mathrm{NO}_{2}$ is reported in ppbv or $\mu \mathrm{g} \mathrm{m}^{-3}$ by regressing total $\mathrm{NO}_{x}$ (reported throughout in ppbv, following the CPCB protocol; $\mathrm{CPCB}, 2015$ ) against the sum of the reported $\mathrm{NO}$ and $\mathrm{NO}_{2}$. We identify that $\mathrm{NO}_{2}$ reported in ppbv (29\% of DPCC, $10 \%$ of CPCB and $74 \%$ of UPPCB data) populates along the 1:1 line, and so we convert these data to $\mu \mathrm{g} \mathrm{m}^{-3}$ using $1.88 \mu \mathrm{g} \mathrm{m}^{-3} \mathrm{ppbv}^{-1}$. The same unit inconsistency does not exist for the $\mathrm{IMD} \mathrm{NO}_{2}$ data. These are reported throughout in ppbv and so are converted to $\mu \mathrm{g} \mathrm{m}^{-3}$.

We only consider surface observations coincident with the OMI record (2005-2018), around the satellite overpass (12:00-15:00 LT). We find that $\mathrm{NO}_{2}$ declines at most sites in London (ranging from $-0.8 \% \mathrm{a}^{-1}$ to $-3.6 \% \mathrm{a}^{-1}$ ) and Birmingham $\left(-1.1 \% \mathrm{a}^{-1}\right.$ to $\left.-3.8 \% \mathrm{a}^{-1}\right)$, with the exception of a few sites influenced by local sources. These include Marylebone Road in central London and Moor Street in Birmingham city centre. Both are impacted by dense traffic and development projects (Carslaw et al., 2016; Harrison and Beddows, 2017). We find that $\mathrm{NO}_{2}$ increases in Moor Street by $6.8 \% \mathrm{a}^{-1}$ from 2013 to 2017 . There are too few long-term sites in Delhi and Kanpur to determine trends at individual sites. We do not filter out sites based on site classification, as this information is not readily available for sites in India. Instead, we remove sites influenced by local effects and not consistent with month-to-month variability representative of the city. This we do by detrending surface $\mathrm{NO}_{2}$ at each site, cross-correlating the detrended data for each site and selecting sites with consistent month-to-month variability $(R>0.5)$ in the detrended data. The original surface $\mathrm{NO}_{2}$ (including the trend) at the selected sites is then used to obtain city-average monthly mean $\mathrm{NO}_{2}$ for comparison to OMI $\mathrm{NO}_{2}$.

The selected sites are shown as triangles in Fig. 1. Filtering for spurious data and selection of consistent sites leads to 14 years of data at 46 sites in London, 5.5 years of data at 6 sites in Birmingham, and 8 years of data at 5 sites in Delhi. There are only 2 sites in Kanpur, but these are not consistent for the brief period of overlap $(R<0.5$ for 2011 2012 ), so we choose the site with the longest record (20112018). For the period of overlap for London and Birmingham (2011-2016), mean city-average midday $\mathrm{NO}_{2}$ is $42.8 \mu \mathrm{g} \mathrm{m}^{-3}$ for London and $26.5 \mu \mathrm{g} \mathrm{m}^{-3}$ for Birmingham. For Delhi and Kanpur (2011-2018 overlap), mean city-average midday $\mathrm{NO}_{2}$ is $91.9 \mu \mathrm{g} \mathrm{m}^{-3}$ for Delhi and $48.4 \mu \mathrm{g} \mathrm{m}^{-3}$ for Kanpur.

We sample satellite observations within the administrative boundaries of the four cities (Fig. 1) to capture the domain that policymakers would target and assess. This is extended a few kilometres beyond the administrative boundary for Birmingham, as otherwise there are too few observations due to frequent clouds and small city size $\left(\sim 300 \mathrm{~km}^{2}\right)$. Error-weighted $\mathrm{OMI} \mathrm{NO}_{2}$ monthly means are estimated for individual pixels centred within the administrative boundaries (including $6.5 \mathrm{~km}$ beyond for Birmingham). Months with $<$ five observations are removed. The number of months retained is $77 \%$ for Birmingham, $>90 \%$ for London, and $>95 \%$ for Delhi and Kanpur. 
Figure 2 compares OMI and surface $\mathrm{NO}_{2}$. The comparison for London and Birmingham is divided into months excluding winter (December-February) and winter months only. Factors that contribute to seasonality in the relationship between tropospheric column and surface $\mathrm{NO}_{2}$ in locations with large seasonal shifts in temperature and solar insolation include reduced photolysis rates, leading to longer $\mathrm{NO}_{x}$ lifetime in winter than summer (Boersma et al., 2009; Kenagy et al., 2018; Shah et al., 2020) and a lower mixed layer height in winter than summer contributing to accumulation of pollution. Maximum mixed layer height for London is $900 \mathrm{~m}$ in winter compared to $1500 \mathrm{~m}$ in summer (Kotthaus and Grimmond, 2018). The slope for Birmingham in winter $\left(0.43 \times 10^{15}\right.$ molecules $\left.\mathrm{cm}^{-2}\left(\mu \mathrm{g} \mathrm{m}^{-3}\right)^{-1}\right)$ is steeper than that for non-winter months $\left(0.27 \times 10^{15}\right.$ molecules $\mathrm{cm}^{-2}$ $\left.\left(\mu \mathrm{g} \mathrm{m}^{-3}\right)^{-1}\right)$, but the difference is not significant. The surface $\mathrm{NO}_{2}$ measurements are also susceptible to interferences (positive biases) from thermal decomposition of $\mathrm{NO}_{x}$ reservoir compounds, such as peroxyacetyl nitrates in chemiluminescence instruments that use heated molybdenum catalysts (Dunlea et al., 2007; Reed et al., 2016). The effect is worse in winter than summer in London and Birmingham due to the abundance of $\mathrm{NO}_{x}$ reservoir compounds in winter (Lamsal et al., 2010). OMI and surface $\mathrm{NO}_{2}$ monthly variability is consistent $(R=0.51-0.71)$, except for London in winter ( $R=0.33)$. The correlation degrades $(R=0.40$ for London, $R=0.54$ for Birmingham) if all months are considered. The seasonal dependence of the relationship between satellite and surface $\mathrm{NO}_{2}$ affects the ability to use OMI $\mathrm{NO}_{2}$ to infer seasonality in the underlying $\mathrm{NO}_{x}$ emissions. The same consistency in monthly mean OMI and surface $\mathrm{NO}_{2}$ in non-winter months $(R \geq 0.6)$ has also been found over the UK city of Leicester (surface area $73 \mathrm{~km}^{2}$ ) (Kramer et al., 2008). Data for all months are used for Delhi and Kanpur, as there is less variability in mixed layer height in India than the UK. Seasonal mean maximum planetary boundary layer height in Delhi varies from $1200 \mathrm{~m}$ in winter to $1400 \mathrm{~m}$ during monsoon months (Nakoudi et al., 2019). Month-to-month variability in tropospheric column and surface $\mathrm{NO}_{2}$ (Fig. 2) is consistent in Delhi $(R=0.55)$ and Kanpur $(R=0.52)$. OMI $\mathrm{NO}_{2}$ exhibits much greater variability for an increment change in surface $\mathrm{NO}_{2}$ in the UK than in India, resulting in orderof-magnitude lower slopes for Delhi and Kanpur (0.033 and $0.039 \times 10^{15}$ molecules $\left.\mathrm{cm}^{-2}\left(\mu \mathrm{g} \mathrm{m}^{-3}\right)^{-1}\right)$ than for London and Birmingham $\left(0.35\right.$ and $0.27 \times 10^{15}$ molecules $\mathrm{cm}^{-2}$ $\left(\mu \mathrm{g} \mathrm{m}^{-3}\right)^{-1}$ ) (Fig. 2). This difference is likely due to a combination of representativeness of surface sites and systematic biases in the OMI $\mathrm{NO}_{2}$ retrieval. In Delhi, the proportion of sites used in Fig. 2 that measure the relatively lower concentration range of $\mathrm{NO}_{2}$ (annual mean $\mathrm{NO}_{2}<50 \mu \mathrm{g} \mathrm{m}^{-3}$ ) is just $20 \%$ compared to $74 \%$ for London, leading to a positive bias in city-average surface $\mathrm{NO}_{2}$ in Delhi. In Kanpur, we use only one site located $600 \mathrm{~m}$ from a national motorway. Aerosols are not explicitly accounted for in the $\mathrm{OMI} \mathrm{NO}_{2}$ retrieval (Krotkov et al., 2017). For very polluted cities like
Delhi and Kanpur, this can lead to an $\sim 20 \%$ underestimate in $\mathrm{OMI} \mathrm{NO}_{2}$ (Choi et al., 2020; Vasilkov et al., 2020).

\subsection{Assessment of IASI $\mathrm{NH}_{3}$}

Figure 3 compares monthly mean IASI and surface $\mathrm{NH}_{3}$ at the three UK EMEP sites. IASI is sampled up to $20 \mathrm{~km}$ around the surface site following the approach of Dammers et al. (2016), and surface observations are sampled around the IASI morning overpass (08:00-11:00 LT) on days with coincident IASI observations. As with $\mathrm{NO}_{2}$, only months with more than five observations are used. A total of $38 \%$ of months are retained for Auchencorth Moss, $62 \%$ for Harwell, and $61 \%$ for Chilbolton Observatory. For the months retained, average $\mathrm{NH}_{3}$ is $1.6 \mu \mathrm{g}$ nitrogen $(\mathrm{N}) \mathrm{m}^{-3}$ for Auchencorth Moss, $2.5 \mu \mathrm{g} \mathrm{N} \mathrm{m}^{-3}$ for Harwell and $6.1 \mu \mathrm{g} \mathrm{N} \mathrm{m}^{-3}$ for Chilbolton Observatory. Chilbolton is southwest of mixed farmland, contributing to levels of $\mathrm{NH}_{3}$ about 3 times higher than at Harwell (Walker et al., 2019). Harwell has a more dynamic range in $\mathrm{NH}_{3}$ and stronger correlation $(R=0.69)$ than the other two sites ( $R=0.37$ for Auchencorth Moss; $R=0.50$ for Chilbolton Observatory). Weak correlation at Auchencorth Moss may be because surface $\mathrm{NH}_{3}$ concentrations are near the instrument detection limit (monthly mean $\mathrm{NH}_{3}<2.0 \mu \mathrm{g} \mathrm{N} \mathrm{m}{ }^{-3}$ ) and also because of low thermal contrast between the surface and overlying atmosphere (Van Damme et al., 2015; Dammers et al., 2016). The slope for Auchencorth Moss $\left(4.02 \times 10^{15}\right.$ molecules $\left.\mathrm{cm}^{-2}\left(\mu \mathrm{g} \mathrm{N} \mathrm{m}^{-3}\right)^{-1}\right)$ is steeper than the slopes observed at sites with greater surface concentrations of $\mathrm{NH}_{3} \quad\left(\right.$ Harwell $=2.23 \times 10^{15}$ molecules cm $\mathrm{cm}^{-2}$ $\left(\mu \mathrm{g} \mathrm{N} \mathrm{m}^{-3}\right)^{-1}$ and Chilbolton $=2.07 \times 10^{15}$ molecules $\mathrm{cm}^{-2}$ $\left(\mu \mathrm{g} \mathrm{N} \mathrm{m}^{-3}\right)^{-1}$ ). Steeper slopes for sites with relatively low $\mathrm{NH}_{3}$ concentrations are consistent with the assessment of earlier IASI $\mathrm{NH}_{3}$ product versions (Van Damme et al., 2015; Dammers et al., 2016).

\subsection{Assessment of MODIS AOD}

Figure 4 compares city-average monthly means of MODIS AOD and $\mathrm{PM}_{2.5}$ for London in 2009-2018 and for Birmingham in 2009-2017. We use $\mathrm{PM}_{2.5}$ data from 24 sites in London and 8 sites in Birmingham. We add 2 more Birmingham sites by deriving $\mathrm{PM}_{2.5}$ from $\mathrm{PM}_{10}$ at 2 sites with only $\mathrm{PM}_{10}$ measurements. We use a conversion factor of $0.85\left(\mathrm{PM}_{2.5}=0.85 \times \mathrm{PM}_{10}\right)$ that we obtain from the slope of SMA regression of hourly $\mathrm{PM}_{2.5}$ and $\mathrm{PM}_{10}$ at 6 sites in Birmingham with both measurements. We use a similar approach as applied to $\mathrm{NO}_{2}$ to assess AOD. Only surface observations around the satellite overpass (12:00-15:00 LT) and with consistent detrended month-to-month variability $(R>0.5)$ are retained to obtain citywide monthly mean $\mathrm{PM}_{2.5}$. This results in 20 sites in London for 2009-2018 and 5 sites in Birmingham for 2009-2017. Mean midday city-average $\mathrm{PM}_{2.5}$ for the period of overlap (2009-2017) is $13.7 \mu \mathrm{g} \mathrm{m}^{-3}$ in Lon- 


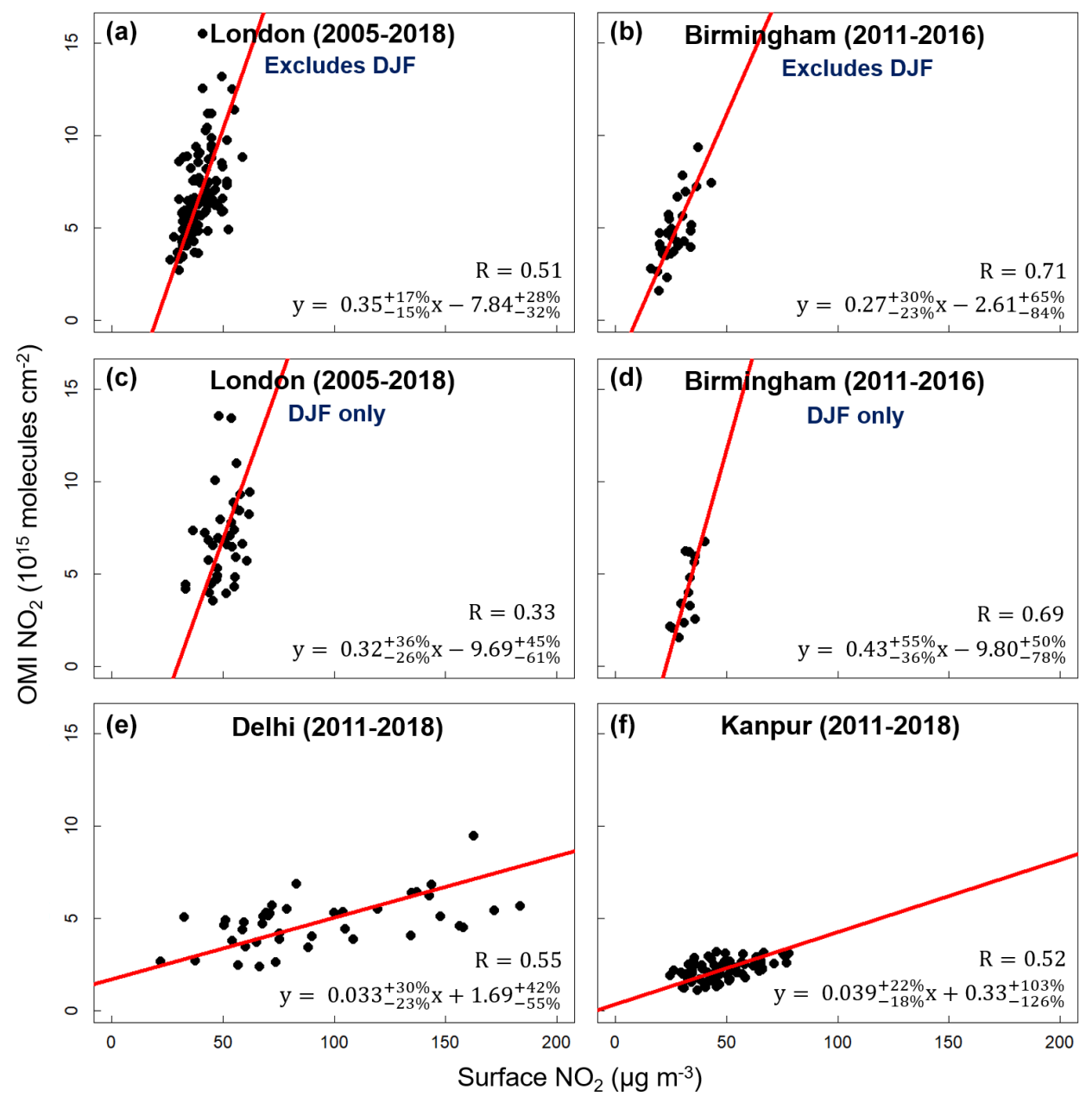

Figure 2. Assessment of $\mathrm{OMI} \mathrm{NO} 2$ with ground-based $\mathrm{NO}_{2}$. Points are monthly means of city-average $\mathrm{NO}_{2}$ from $\mathrm{OMI}$ and the surface networks for London (a, c), Birmingham (b, d), Delhi (e), and Kanpur (f). UK cities include panels with all months except DecemberFebruary (DJF) (a, b) and DJF only (c, d). Data for all months are given for cities in India. The red line is the standard major axis (SMA) regression. Values inset are Pearson's correlation coefficients and regression statistics. Relative errors on the slopes and intercepts are the $95 \%$ confidence interval $(\mathrm{CI})$.
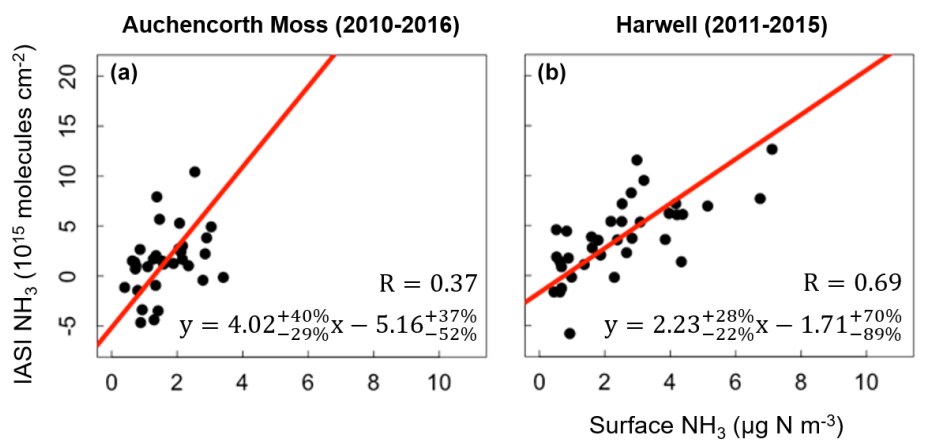

Chilbolton Observatory (2016-2018)

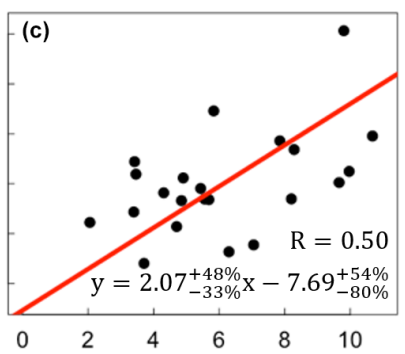

Figure 3. Assessment of IASI $\mathrm{NH}_{3}$ with ground-based $\mathrm{NH}_{3}$ at UK EMEP sites. Points are monthly means from IASI and the surface sites Auchencorth Moss (a), Harwell (b), and Chilbolton Observatory (c). The red line is the SMA regression. Values inset are Pearson's correlation coefficients and regression statistics. Relative errors on the slope and intercept are the $95 \%$ CI. Locations of UK EMEP sites are indicated in Fig. 1. 
don and $11.3 \mu \mathrm{g} \mathrm{m}^{-3}$ in Birmingham. MODIS AOD monthly means are estimated for London by averaging the pixels centred within its administrative boundary and for Birmingham within and $6.5 \mathrm{~km}$ beyond the administrative boundary, as with $\mathrm{OMI} \mathrm{NO}$ (Sect. 3.1). We remove months with $<160$ observations, equivalent in spatial coverage to 5 OMI pixels at nadir (the threshold used for OMI). After filtering, $53 \%$ of months are removed for London and $72 \%$ for Birmingham, mostly in winter. Fewer months than OMI are retained, as MODIS uses stricter cloud filtering. The correlations in Fig. 4 are weak ( $R=0.34$ for London, $R=0.23$ for Birmingham) and do not improve if we apply a less strict threshold for the number of observations required to calculate monthly means. The poor correlation may be due to environmental factors that complicate the relationship between AOD and surface $\mathrm{PM}_{2.5}$, such as variability in meteorological conditions, aerosol composition, enhancements in aerosols above the boundary layer, and the aerosol radiative properties (Schaap et al., 2009; van Donkelaar et al., 2016; Shaddick et al., 2018; Sathe et al., 2019). We find that the same assessment is not feasible for Delhi or Kanpur as the record of surface $\mathrm{PM}_{2.5}$ and $\mathrm{PM}_{10}$ in these cities is too short.

Figure 5 compares time series of monthly mean cityaverage MODIS AOD and surface $\mathrm{PM}_{2.5}$ in London (20092018) and Birmingham (2009-2017) to assess whether the weak correlation in Fig. 4 affects agreement in trends of the two quantities. $\mathrm{PM}_{2.5}$ is longer lived than $\mathrm{NO}_{2}$, so trends in $\mathrm{PM}_{2.5}$ (lifetime order weeks) for the limited number of sites mostly located in central London should be more representative of variability across the city than the surface sites of $\mathrm{NO}_{2}$ (lifetime order hours against conversion to temporary reservoirs). The steeper decline in surface $\mathrm{PM}_{2.5}$ in Birmingham $\left(3.7 \% \mathrm{a}^{-1}\right)$ than in London $\left(2.7 \% \mathrm{a}^{-1}\right)$ is reproduced in the AOD record $\left(3.7 \% \mathrm{a}^{-1}\right.$ in Birmingham; $2.5 \% \mathrm{a}^{-1}$ in London), although the AOD trends are not significant. In the two UK cities, surface $\mathrm{PM}_{2.5}$ peaks in spring, whereas AOD peaks in the summer, determined from multi-year monthly means (not shown). There are too few $\mathrm{PM}_{2.5}$ measurements in Delhi and Kanpur to compare long-term trends.

We compare the MODIS AOD product against groundtruth AOD from AERONET at long-term sites in Kanpur and Chilbolton to assess whether errors in satellite retrieval of AOD contribute to the weak temporal correlation between MODIS AOD and surface $\mathrm{PM}_{2.5}$. Daily AERONET AOD at $550 \mathrm{~nm}$ is estimated by interpolation using the secondorder polynomial relationship between the logarithmic AOD and logarithmic wavelengths at 440,500,675, and $870 \mathrm{~nm}$ (Kaufman, 1993; Eck et al., 1999; Levy et al., 2010; Li et al., 2012; Georgoulias et al., 2016). AERONET is sampled $30 \mathrm{~min}$ around the MODIS overpass, and MODIS is sampled $27.5 \mathrm{~km}$ around the AERONET site (Levy et al., 2010; Petrenko et al., 2012; Georgoulias et al., 2016; McPhetres and Aggarwal, 2018). Months with fewer than 160 MODIS observations are removed.
Figure 6 compares coincident AOD monthly means from MODIS and AERONET for Kanpur and Chilbolton. Monthly variability in MODIS and AERONET AOD is consistent at both sites $(R \geq 0.8)$. MODIS exhibits no appreciable bias at Kanpur. There is positive variance (slope $=1.4$ ) at Chilbolton that may result from sensitivity to errors in surface reflectivity at low AOD (Remer et al., 2013; Bilal et al., 2018) and residual cloud contamination (Wei et al., 2018, 2020). Mhawish et al. (2017) obtained similarly strong correlation ( $R=0.8$ ), but positive bias ( $26 \%$ ), of MODIS AOD at Kanpur from an earlier $3 \mathrm{~km}$ MODIS AOD product (Collection 6).

\section{Air quality trends in London, Birmingham, Delhi, and Kanpur}

The consistency we find between satellite and ground-based monthly mean city-average $\mathrm{NO}_{2}$ (Fig. 2) and rural $\mathrm{NH}_{3}$ (Fig. 3) and trends in city-average $\mathrm{PM}_{2.5}$ (Fig. 5) supports the use of the satellite record to constrain surface air quality. Variability in $\mathrm{NO}_{2}, \mathrm{HCHO}$, and $\mathrm{NH}_{3}$ columns can also be related to precursor emissions of $\mathrm{NO}_{x}, \mathrm{NMVOCs,} \mathrm{and} \mathrm{NH}_{3}$ (Martin et al., 2003; Lamsal et al., 2011; Marais et al., 2012; Zhu et al., 2014; Dammers et al., 2019), as their lifetimes against conversion to temporary or permanent sinks are relatively short, varying from $1-12 \mathrm{~h}$ depending on photochemical activity, abundance of pre-existing acidic aerosols, and proximity to large sources (Jones et al., 2009; Richter, 2009; Paulot et al., 2017; Van Damme et al., 2018). We adopt the same sampling approach as used to evaluate $\mathrm{OMI} \mathrm{NO}_{2}$. That is, we sample the satellite observations within the city administrative boundaries for London, Delhi, and Kanpur and extend the sampling domain for Birmingham beyond the administrative boundary by $6.5 \mathrm{~km}$ for OMI and MODIS and $10 \mathrm{~km}$ for IASI.

We apply the Theil-Sen single median estimator to the time series and also test the effect of fitting a non-linear function (Weatherhead et al., 1998; van der A et al., 2006; Pope et al., 2018) to account explicitly for seasonality:

$Y_{m}=A+B X_{m}+C \sin \left(\omega X_{m}+\varnothing\right)$.

$Y_{m}$ is city-average satellite observations for month $m, X_{m}$ is the number of months from the start month (January 2005 for OMI and MODIS, and January 2008 for IASI), and $A, B, C$, and $\varnothing$ are fit parameters. $A$ is the city-average satellite observations in the start month, $B$ is the linear trend, and $\left[C \sin \left(\omega X_{m}+\varnothing\right)\right]$ is the seasonal component that includes the amplitude $C$, frequency $\omega$ (fixed to 12 months), and phase shift $\varnothing$. We only show the fit in Eq. (1) if the trend $B$ is different to that obtained with the Theil-Sen approach. The confidence intervals (CIs) for the Theil-Sen trends are estimated using bootstrap resampling, and trends are considered significant for $p$ value $<0.05$, that is, if the $95 \%$ CI range does not intersect zero. 


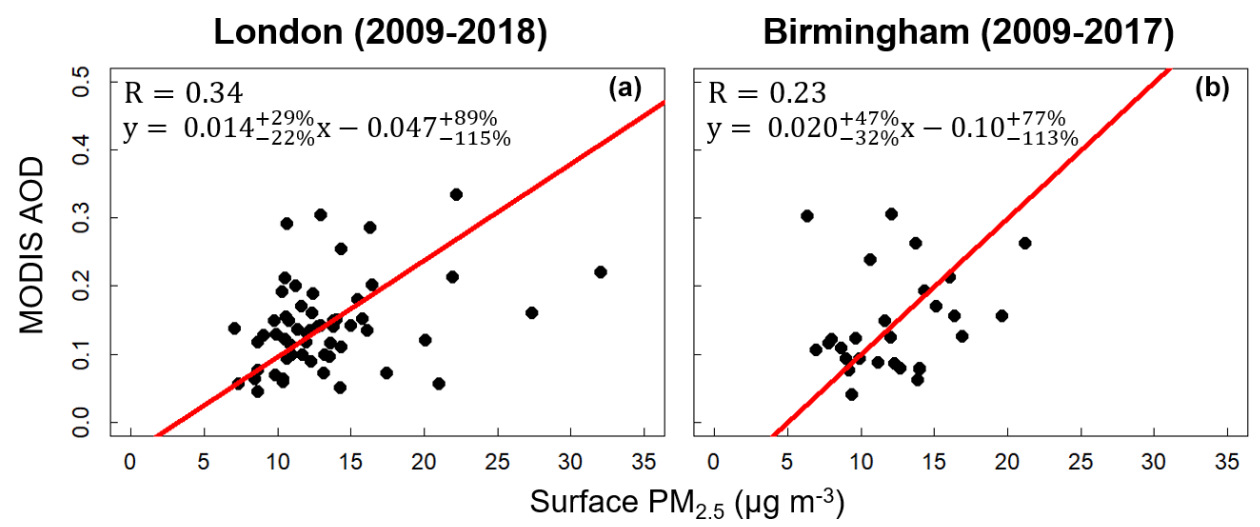

Figure 4. Assessment of MODIS AOD with surface $\mathrm{PM}_{2.5}$ in London (a) and Birmingham (b). Points are monthly means of city-average AOD from MODIS and $\mathrm{PM}_{2.5}$ from surface networks for London and Birmingham. The red line is the SMA regression. Values inset are Pearson's correlation coefficients and regression statistics. Relative errors on the slopes and intercepts are the $95 \%$ CI.

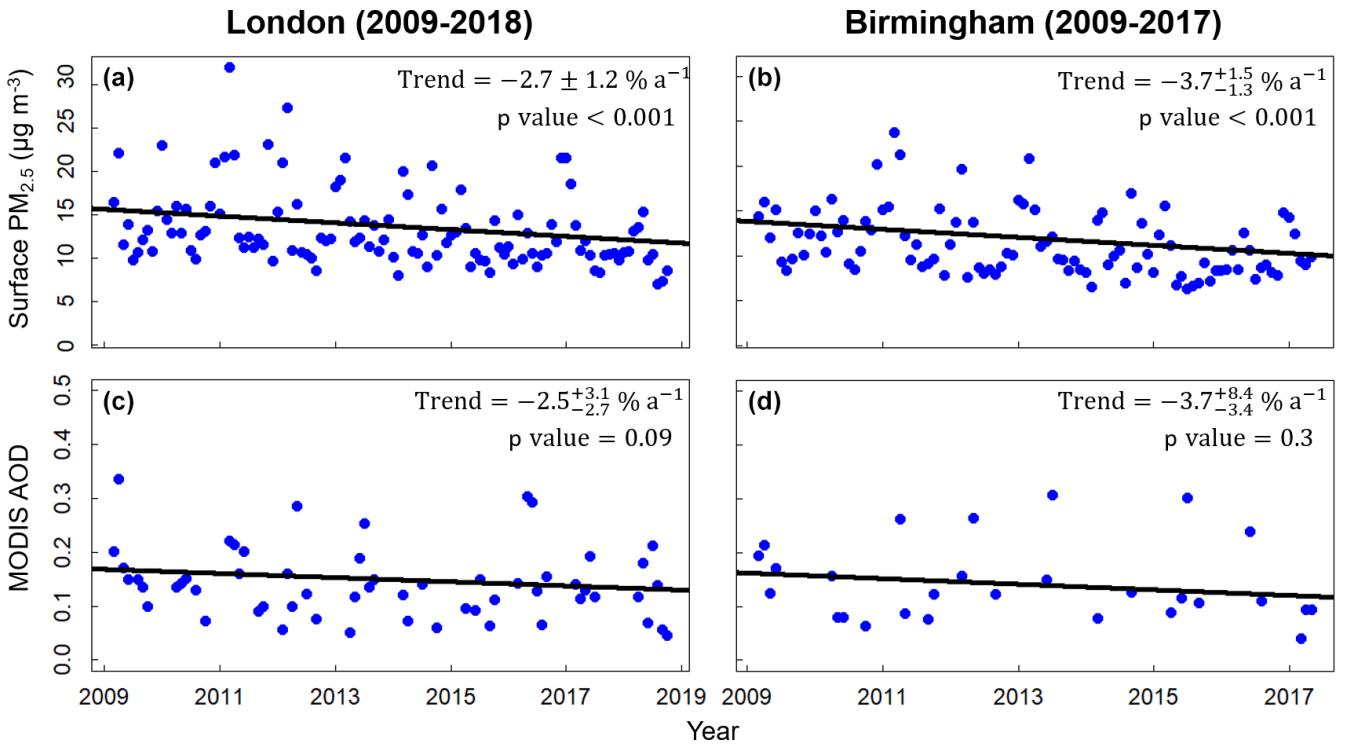

Figure 5. Time series of surface $\mathrm{PM}_{2.5}$ and MODIS AOD in 2009-2018 for London (a, c) and 2009-2017 for Birmingham (b, d). Points are city-average monthly means of $\mathrm{PM}_{2.5}$ from the surface network $(\mathbf{a}, \mathbf{b})$ and AOD from MODIS (c, d). Black lines are trends obtained with the Theil-Sen single median estimator. Values inset are annual trends and $p$ values. Absolute errors on the trends are the $95 \%$ CI. Trends are considered significant at the $95 \%$ CI $(p$ value $<0.05)$.

Figure 7 shows the time series of monthly means of city-average $\mathrm{OMI} \mathrm{NO}_{2}$ in the four cities for 2005-2018. Decline in $\mathrm{OMI} \mathrm{NO}_{2}$ in both London and Birmingham is $2.5 \% \mathrm{a}^{-1}$ and is significant. In Delhi, the $\mathrm{OMI} \mathrm{NO}_{2}$ increase is $2.0 \% \mathrm{a}^{-1}$ and is significant ( $p$ value $=0.003$ ), whereas the increase in Kanpur of $0.9 \% \mathrm{a}^{-1}$ is not $(p$ value $=0.06)$. The relationship between tropospheric column and surface $\mathrm{NO}_{2}$ in London and Birmingham exhibits seasonality (Fig. 2). This is in part due to seasonality in mixing depth. We find that excluding the winter months in the time series has only a small effect on the trend. $\mathrm{NO}_{2}$ should exhibit seasonality in all cities due to seasonal variability in its lifetime and sources (van der A et al., 2008). The fit in Eq. (1) yields significant seasonality for all cities ( $p$ value $<0.05$ for the amplitude of the seasonality, $C$ ), but the linear trends are similar to those in Fig. 7: $-2.4 \% \mathrm{a}^{-1}$ for London and Birmingham; unchanged for Delhi and Kanpur.

Comparison of the OMI $\mathrm{NO}_{2}$ trends in Fig. 7 to surface observations is only possible for London, where there are 46 sites with consistent month-to-month variability representative of the city that operated continuously from 2005 to 2018 . The trend obtained for $\mathrm{OMI} \mathrm{NO}_{2}$ in London $\left(-2.5 \% \mathrm{a}^{-1}\right)$ is steeper than we estimate with the surface monitoring sites shown as triangles in Fig. $1\left(1.8 \% \mathrm{a}^{-1}\right.$ for 2005-2018). Most sites are in central London, and $\mathrm{NO}_{2}$ trends in outer London are 1.6 times steeper than in central London (Carslaw et al., 


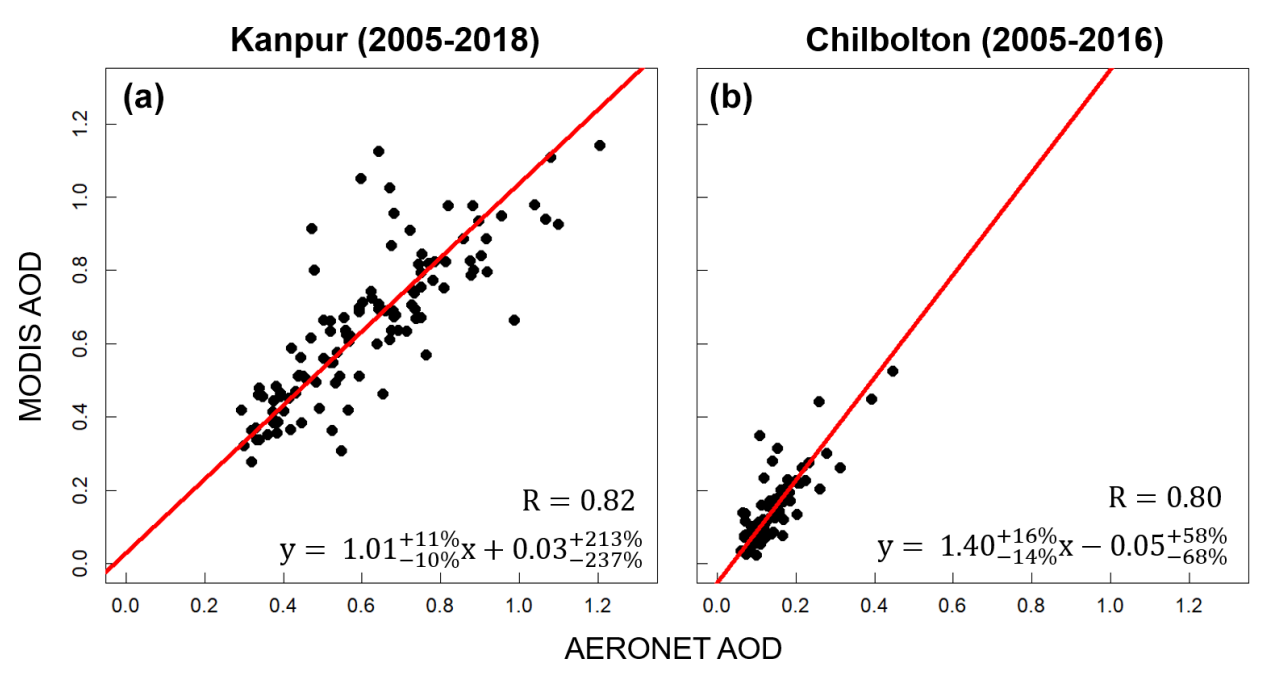

Figure 6. Validation of MODIS AOD with AERONET AOD in Kanpur and Chilbolton. Points are monthly means of MODIS and AERONET AOD for Kanpur (a) and Chilbolton (b). The red line is the SMA regression. Values inset are Pearson's correlation coefficients and regression statistics. Relative errors on the slopes and intercepts are the $95 \%$ CI.

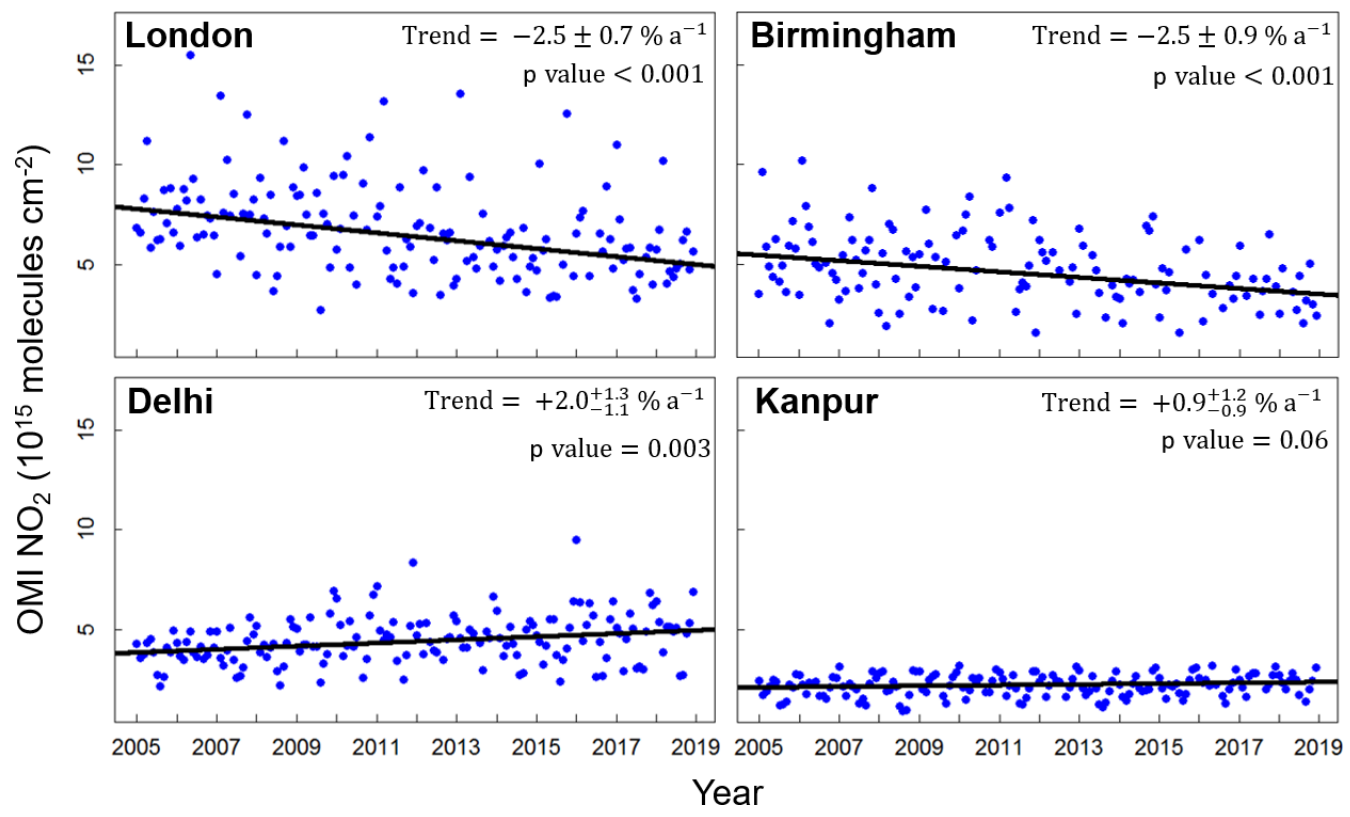

Figure 7. Time series of $\mathrm{OMI} \mathrm{NO}_{2}$ in 2005-2018 for London, Birmingham, Delhi, and Kanpur. Points are city-average monthly means. Black lines are trends obtained with the Theil-Sen single median estimator. Values inset are annual trends and $p$ values. Absolute errors on the trends are the $95 \% \mathrm{CI}$.

2011). The decline in $\mathrm{NO}_{2}$ in the two UK cities is less than the rate of decline in national $\mathrm{NO}_{x}$ emissions $\left(3.8 \% \mathrm{a}^{-1}\right)$ for 2005-2017 from the national bottom-up emission inventory (Defra, 2019a). This may reflect a combination of factors. There is less steep decline in $\mathrm{NO}_{x}$ emissions in London compared to the national total that may in part be due to discrepancies between real-world and reported diesel $\mathrm{NO}_{x}$ emissions (Fontaras et al., 2014), sustained heavy traffic in central London, and an increase in $\mathrm{NO}_{2}$-to- $\mathrm{NO}_{x}$ emission ratios dampening decline in $\mathrm{NO}_{2}$ (Grange et al., 2017). There is also weakened sensitivity of the tropospheric column to changes in surface $\mathrm{NO}_{2}$ due to a gradual increase in the relative contribution of the free tropospheric background to the tropospheric column (Silvern et al., 2019). This weakening of the trend in the tropospheric column will likely be less in London than in Birmingham, due to greater local surface emissions in large cities such as London (Zara et al., 2021). The positive trends in Delhi and Kanpur likely reflect a 2fold increase in vehicle ownership in Delhi (Govt. of Delhi, 2019), rapid industrialisation in Kanpur (Nagar et al., 2019), 
and the limited effect of air quality policies on pollution sources. This is corroborated by $\mathrm{NO}_{x}$ emissions compliance failures at more than $50 \%$ of coal-fired power plants in Delhi and the surrounding area (Pathania et al., 2018). The lack of trend reversal in Delhi, despite implementation of air quality policies, is consistent with the lack of trend reversal reported by Georgoulias et al. (2019). They used a 21-year record (1996-2017) of multiple space-based sensors to estimate a significant and sustained increase in $\mathrm{NO}_{2}$ of $3.1 \% \mathrm{a}^{-1}$ in Delhi. By the end of 2018, tropospheric column $\mathrm{NO}_{2}$ is similar in London and Delhi $\left(5.7 \times 10^{15}\right.$ molecules $\mathrm{cm}^{-2}$; Fig. 7), but $\mathrm{OMI} \mathrm{NO} \mathrm{N}_{2}$ over India may be biased low, due to the presence of optically thick aerosols (AOD $>0.4$; Fig. 6 ) that are not explicitly accounted for in the retrieval (Sect. 3.1).

The direction of the trends for all four cities is consistent with other trend studies, with differences in the absolute size of the trend due to differences in instruments, time periods, and sampling domains. Pope et al. (2018) observed declines in $\mathrm{OMI} \mathrm{NO}_{2}$ for 2005-2015 of $2.3 \pm 0.5 \times 10^{14}$ molecules $\mathrm{cm}^{-2} \mathrm{a}^{-1}$ for London and $1.1 \pm$ $0.5 \times 10^{14}$ molecules $\mathrm{cm}^{-2} \mathrm{a}^{-1}$ for Birmingham. We obtain a similar trend for Birmingham but a steeper decline for London of $2.6 \times 10^{14}$ molecules $\mathrm{cm}^{-2} \mathrm{a}^{-1}$ using our sampling domain for 2005-2015, though the difference is not significant. Schneider et al. (2015) obtained less steep and nonsignificant changes in $\mathrm{NO}_{2}$ in London $\left(-1.7 \pm 1.2 \% \mathrm{a}^{-1}\right)$ and Delhi $\left(1.4 \pm 1.2 \% \mathrm{a}^{-1}\right)$ from the SCanning Imaging Absorption spectroMeter for Atmospheric CHartographY (SCIAMACHY) for 2002-2013. Trends in $\mathrm{OMI} \mathrm{NO}_{2}$ for 2005-2014 from ul-Haq et al. (2015) are similar to ours for Delhi $\left(2.0 \% \mathrm{a}^{-1}\right)$ but lower for Kanpur $\left(0.2 \% \mathrm{a}^{-1}\right)$. Studies have also combined multiple instruments to derive trends since the mid-1990s. These find decreases in $\mathrm{NO}_{2}$ over London of $0.7 \% \mathrm{a}^{-1}$ for $1996-2006$ (van der A et al., 2008) and $1.7 \% \mathrm{a}^{-1}$ for a longer observing period (1996-2011) (Hilboll et al., 2013) and a consistent increase for Delhi of $7.4 \% \mathrm{a}^{-1}$ in 1996-2006 (van der A et al., 2008) and 19962011 (Hilboll et al., 2013), much steeper than ours in Fig. 7.

Figure 8 shows time series of monthly means of cityaverage IASI $\mathrm{NH}_{3}$ in the four cities for 2008-2018. Mean IASI $\mathrm{NH}_{3}$ is $15-20$ times more in Delhi and Kanpur than in London and Birmingham due to larger emissions of $\mathrm{NH}_{3}$ in the IGP, higher ambient temperatures promoting volatilisation of $\mathrm{NH}_{3}$, and greater sensitivity of IASI to $\mathrm{NH}_{3}$ due to greater thermal contrast between the surface and the atmosphere over India (Van Damme et al., 2015; Dammers et al., 2016; T. Wang et al., 2020). IASI $\mathrm{NH}_{3}$ decreases by $0.1 \% \mathrm{a}^{-1}$ in Kanpur, $0.6 \% \mathrm{a}^{-1}$ in Birmingham, and $2.4 \% \mathrm{a}^{-1}$ in London and increases by $0.5 \% \mathrm{a}^{-1}$ in Delhi. None of the trends are significant. Measurements of surface $\mathrm{NH}_{3}$ from continuous monitors deployed in Delhi in April 2010 to July 2011 exhibit the same seasonality as IASI $\mathrm{NH}_{3}$, peaking in the monsoon season (July-September) (Singh and Kulshrestha, 2012). We investigated the effect of $\mathrm{NH}_{3}$ seasonality on the trend using Eq. (1) (solid grey lines in Fig. 8).
Similar to $\mathrm{NO}_{2}$, all four cities show significant seasonality ( $p$ value $<0.05$ for the amplitude of the seasonality, $C$ ). The linear trends (dashed grey lines in Fig. 8) are more positive than those obtained with Theil-Sen for all four cities but are still not significant. This leads to a trend reversal in Kanpur $\left(+1.0 \% \mathrm{a}^{-1}\right)$ and Birmingham $\left(+2.1 \% \mathrm{a}^{-1}\right)$, steeper increase in Delhi $\left(+3.7 \% \mathrm{a}^{-1}\right)$, and a less negative trend in London $\left(-0.6 \% \mathrm{a}^{-1}\right)$.

Relating trends in $\mathrm{NH}_{3}$ columns to trends in $\mathrm{NH}_{3}$ emissions is complicated by partitioning of $\mathrm{NH}_{3}$ to aerosols to form ammonium and dependence of this process on pre-existing aerosols that have declined in abundance across the UK due largely to controls on precursor emissions of $\mathrm{SO}_{2}$ (Vieno et al., 2014). Harwell and Auchencorth Moss include measurements of gas-phase $\mathrm{NH}_{3}$ and aerosol-phase ammonium in $\mathrm{PM}_{2.5}$. These exhibit large and distinct seasonality, so we use Eq. (1) to estimate changes of $-0.096 \mu \mathrm{g} \mathrm{N} \mathrm{m}^{-3} \mathrm{a}^{-1}$ for ammonium and $+0.031 \mu \mathrm{g} \mathrm{N} \mathrm{m}^{-3} \mathrm{a}^{-1}$ for $\mathrm{NH}_{3}$ at Auchencorth Moss in 2008-2012 and similar changes at Harwell in 2012-2015 of $-0.10 \mu \mathrm{g} \mathrm{N} \mathrm{m}^{-3} \mathrm{a}^{-1}$ for ammonium and $+0.035 \mu \mathrm{g} \mathrm{N} \mathrm{m}^{-3} \mathrm{a}^{-1}$ for $\mathrm{NH}_{3}$. Only the decline in ammonium at Auchencorth Moss is significant. This suggests the increase in rural $\mathrm{NH}_{3}$ includes contributions from unregulated agricultural emissions and reduced partitioning of $\mathrm{NH}_{3}$ to pre-existing aerosols. The opposite trend (decline) in $\mathrm{NH}_{3}$ in London obtained with Theil-Sen and Eq. (1) (Fig. 8) may be because decline in local vehicular emissions of $\mathrm{NH}_{3}$ with a shift in catalytic converter technology (Richmond et al., 2020) outweighs the increase in $\mathrm{NH}_{3}$ from waste and domestic combustion (Defra, 2019a), and nearby agriculture (Vieno et al., 2016) and offsets reduced partitioning of $\mathrm{NH}_{3}$ to acidic aerosols with decline in sulfate. The opposite effect would be expected in Delhi due to nationwide increases in $\mathrm{SO}_{2}$ emissions and sulfate abundance (Klimont et al., 2013; Aas et al., 2019). That is, the increase in $\mathrm{NH}_{3}$ emissions may be steeper than the increase in $\mathrm{NH}_{3}$ columns in Fig. 8 due to a corresponding increase in partitioning of $\mathrm{NH}_{3}$ to pre-existing aerosols as these become more abundant.

Figure 9 shows the time series of city-average monthly mean OMI HCHO for the four cities for 2005-2018 after removing the background contribution from oxidation of methane and other long-lived volatile organic compounds (VOCs) to isolate variability in the column due to reactive NMVOCs (Zhu et al., 2016). A representative background is obtained as monthly mean OMI HCHO over the remote Atlantic Ocean $\left(25-35^{\circ} \mathrm{N}, 35-45^{\circ} \mathrm{W}\right)$ for the UK and the remote Indian Ocean $\left(10-20^{\circ} \mathrm{S}, 70-80^{\circ} \mathrm{E}\right)$ for India. The non-linear function in Eq. (1) is fit to these background $\mathrm{HCHO}$ values and used to subtract the background contribution, as in Marais et al. (2012), from the city-average monthly means. OMI HCHO columns from oxidation of reactive NMVOCs in Delhi and Kanpur are almost twice those in London and Birmingham due to a combination of unregulated sources (Venkataraman et al., 2018) and high temper- 


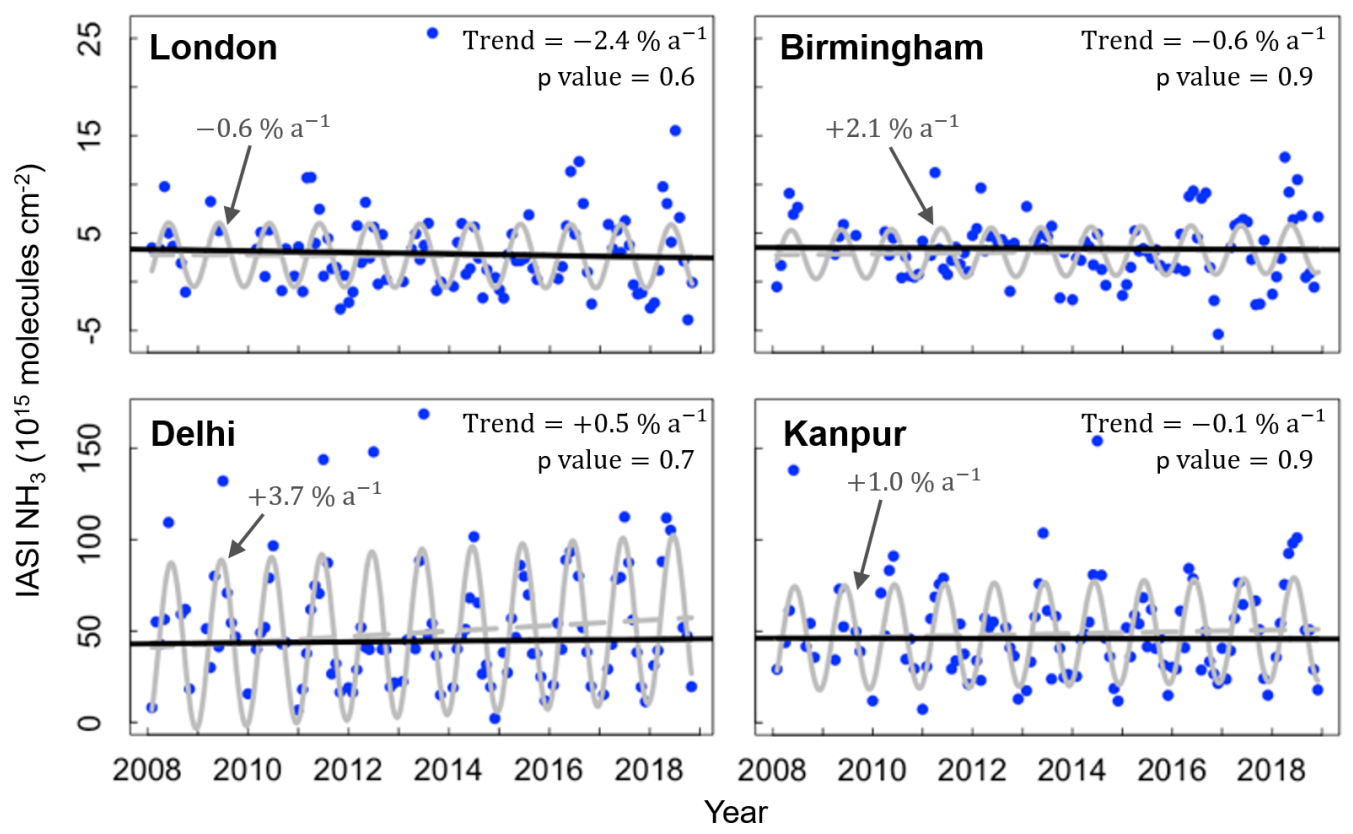

Figure 8. Time series of IASI NH 3 in 2008-2018 for London, Birmingham, Delhi, and Kanpur. Points are city-average monthly means. Black lines are trends obtained with the Theil-Sen single median estimator. The grey lines are the fit (solid) and trend component $(B)$ (dashed) obtained with Eq. (1). Values inset are annual trends and $p$ values for the Theil-Sen fit (in black) and annual trends obtained with Eq. (1) (grey). Trend errors (not shown) exceed $\pm 150 \%$ in all cities.

atures enhancing emissions of isoprene, a dominant $\mathrm{HCHO}$ precursor in India (Surl et al., 2018; Chalilyakunnel et al., 2019). The trends suggest reactive NMVOCs emissions have decreased in Birmingham $\left(1.6 \% \mathrm{a}^{-1}\right)$ and increased in London $\left(0.5 \% \mathrm{a}^{-1}\right)$, Delhi $\left(1.9 \% \mathrm{a}^{-1}\right)$, and Kanpur $\left(1.0 \% \mathrm{a}^{-1}\right)$. Only Delhi has a significant trend. The spread in values increases for Delhi and Kanpur from 19\%-24\% relative to the trend line in 2005 to $31 \%-40 \%$ in 2018 . The change in the spread of values does not appear to be due to loss of data resulting from the row anomaly, as the change in the spread of $\mathrm{HCHO}$ over time is similar if we remove all pixels affected by the row anomaly for the entire data record (2005-2018). OMI HCHO slant columns (HCHO along the instrument viewing path) remain relatively stable throughout the OMI record (Zara et al., 2018), so the increase in variability may reflect more extreme emissions from seasonal sources like open fires in the IGP (Jethva et al., 2019). The trends from satellite observations of HCHO in megacities obtained by De Smedt et al. (2010) using multiple instruments for 19972009 are consistent with ours for Delhi $\left(1.6 \pm 0.7 \% \mathrm{a}^{-1}\right)$ but opposite for London $\left(-0.4 \pm 2.1 \% \mathrm{a}^{-1}\right)$. There is a shift in the magnitude of the $\mathrm{HCHO}$ trend for London around 2011 (Fig. 9) from an increase of $0.3 \% \mathrm{a}^{-1}(p$ value $=0.9)$ in 2005-2011 to a rapid increase of $9.3 \% \mathrm{a}^{-1}$ (95\% CI: $0 \% \mathrm{a}^{-1}-26 \% \mathrm{a}^{-1}$ ) in 2012-2018. Visually the data suggest a decline in OMI HCHO in 2005-2011, as in De Smedt et al. (2010), but our trend estimate for 2005-2011 is affected by a limited analysis period and large interannual variability.
According to the UK bottom-up emission inventory, national NMVOCs emissions decreased by $2.4 \% \mathrm{a}^{-1}$ from 2005 to 2017 (Defra, 2019a). This is supported by decline in short-chain hydrocarbons measured at Harwell from 2$3 \mu \mathrm{g} \mathrm{m}^{-3}$ in 2008 to $0.8-0.9 \mu \mathrm{g} \mathrm{m}^{-3}$ in 2015 . These include hydrocarbons from vegetation (isoprene and monoterpenes) and vehicles (light alkanes and aromatics) but exclude oxygenated VOCs (OVOCs) that in the UK include increasing contributions from domestic combustion, the food and beverage industry, and household products (Defra, 2019a). OVOCs have relatively high HCHO yields (Millet et al., 2006), and VOC concentrations measured during field campaigns in London and cities in India, including Delhi, are dominated by OVOCs (>60\% in London) (Valach et al., 2014; Sahu et al., 2016; L. Wang et al., 2020). In London, OVOCs also dominate inferred fluxes of VOCs (Langford et al., 2010) and reactivity of VOCs with the main atmospheric oxidant, $\mathrm{OH}$ (Whalley et al., 2016). The rapid increase in HCHO also has implications for ozone air pollution and the radical budget in London, as ozone formation is VOC-limited, and $\mathrm{HCHO}$ photolysis is the second largest source of hydrogen oxide radicals $\left(\mathrm{HO}_{x} \equiv \mathrm{OH}+\mathrm{HO}_{2}\right)$ in London (Whalley et al., 2018).

Figure 10 shows the time series of city-average MODIS AOD monthly means in the four cities for 2005-2018. Trends in AOD are significant in all four cities and range from a decline of $4.2 \% \mathrm{a}^{-1}$ in Birmingham to an increase of $3.1 \% \mathrm{a}^{-1}$ in Kanpur. Mean AOD in Delhi and Kanpur is on average 5- 


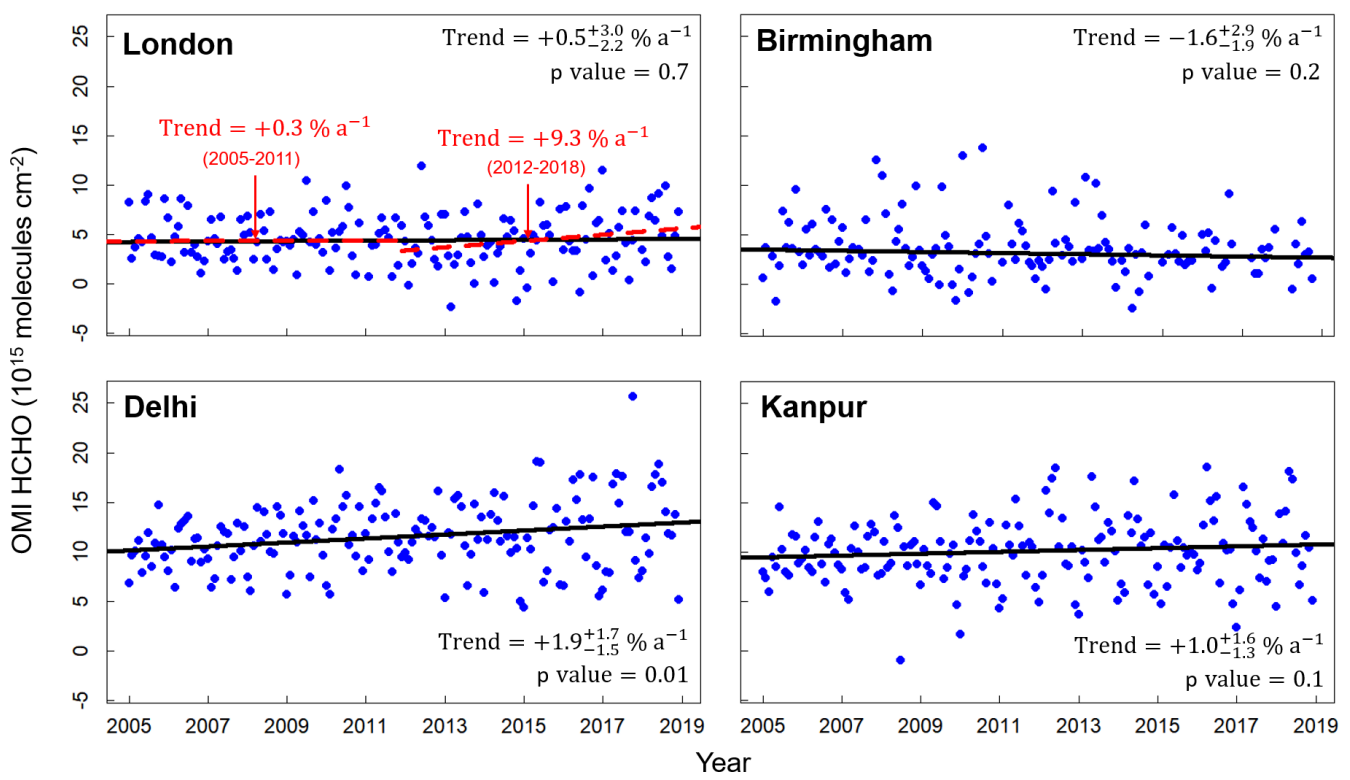

Figure 9. Time series of OMI HCHO for London, Birmingham, Delhi, and Kanpur. Points are city-average monthly means of OMI HCHO after removing the background contribution (see text for details). Solid black lines are trends for 2005-2018 obtained with the Theil-Sen single median estimator. Values inset are annual trends and $p$ values. Absolute errors on the trends are the $95 \%$ CI. Dashed red lines show trend lines for London in 2005-2011 and 2012-2018, and red text shows corresponding annual trends.

6 times more than in London and Birmingham, due to large local anthropogenic emissions, nearby agricultural emissions of $\mathrm{PM}_{2.5}$ and its precursors in the IGP, and long-range transport of desert dust (David et al., 2018). Our results, as absolute AOD trends for London $\left(-0.004 \mathrm{a}^{-1}\right)$ and Birmingham $\left(-0.007 \mathrm{a}^{-1}\right)$ for $2005-2018$, are similar to trends obtained by Pope et al. (2018) for 2005-2015 $\left(-0.006 \mathrm{a}^{-1}\right.$ for London; $-0.005 \mathrm{a}^{-1}$ for Birmingham). Our trends for both cities in India are less steep than the increase for Delhi $\left(4.9 \% \mathrm{a}^{-1}\right)$ obtained for 2000-2010 with the MODIS $10 \mathrm{~km}$ AOD product (Ramachandran et al., 2012) and for Kanpur $\left(10.3 \% \mathrm{a}^{-1}\right)$ obtained for 2001-2010 with AERONET AOD at the Kanpur AERONET site (Kaskaoutis et al., 2012). This may reflect a recent dampening of the trend or differences in data products and sampling domain/period. Sulfate from coal-fired power plants in India makes a large contribution to $\mathrm{PM}_{2.5}$ (Weagle et al., 2018), and emissions from these nearly doubled from 2004 to 2015 (Fioletov et al., 2016).

\section{Conclusions}

Satellite observations of atmospheric composition provide long-term and consistent global coverage of air pollutants. We assessed the ability of satellite observations of nitrogen dioxide $\left(\mathrm{NO}_{2}\right)$ and formaldehyde (HCHO) from OMI for 2005-2018, ammonia $\left(\mathrm{NH}_{3}\right)$ from IASI for 2008-2018, and aerosol optical depth (AOD) from MODIS for 2005-2018 to provide constraints on long-term changes in city-average $\mathrm{NO}_{2}$, reactive NMVOCs, $\mathrm{NH}_{3}$, and $\mathrm{PM}_{2.5}$, respectively in four cities: two in the UK (London and Birmingham) and two in India (Delhi and Kanpur).

Assessment of satellite observations against ground-based measurements followed careful screening of the in situ measurements for poor-quality data, correcting $\mathrm{NO}_{2}$ data reported in inconsistent units at monitoring sites in Delhi and Kanpur and removing sites influenced by local sources. OMI $\mathrm{NO}_{2}$ reproduces monthly variability in surface concentrations of $\mathrm{NO}_{2}$ in cities, whereas satellite AOD reproduces trends, but not monthly variability, in $\mathrm{PM}_{2.5}$ in cities. MODIS and AERONET AOD are consistent at long-term monitoring sites in Kanpur and a UK EMEP site in southern England. IASI $\mathrm{NH}_{3}$ is consistent with monthly variability in surface $\mathrm{NH}_{3}$ concentrations at two of three rural UK EMEP sites. There were no appropriate measurements of reactive NMVOCs to compare to OMI HCHO.

According to the long-term record from Earth observations, $\mathrm{NO}_{2}, \mathrm{PM}_{2.5}$, and NMVOCs increased in Delhi and Kanpur. There is no reversal in the increase in $\mathrm{NO}_{2}$ or $\mathrm{PM}_{2.5}$ in Delhi or Kanpur, as would be expected from successful implementation of air pollution mitigation measures. In all four cities, the magnitude and direction of trends in $\mathrm{NH}_{3}$ are sensitive to treatment of $\mathrm{NH}_{3}$ seasonality, and none of the $\mathrm{NH}_{3}$ trends are significant. In London and Birmingham, $\mathrm{NO}_{2}$ and $\mathrm{PM}_{2.5}$ decrease, and $\mathrm{HCHO}$, a proxy for reactive NMVOCs emissions, decreases in Birmingham but exhibits a recent (2012-2018) sharp $\left(>9 \% \mathrm{a}^{-1}\right)$ increase in London. This may reflect increased emissions of oxygenated VOCs and long-chain hydrocarbons from household products, the food and beverage industry, and residential fuelwood burn- 


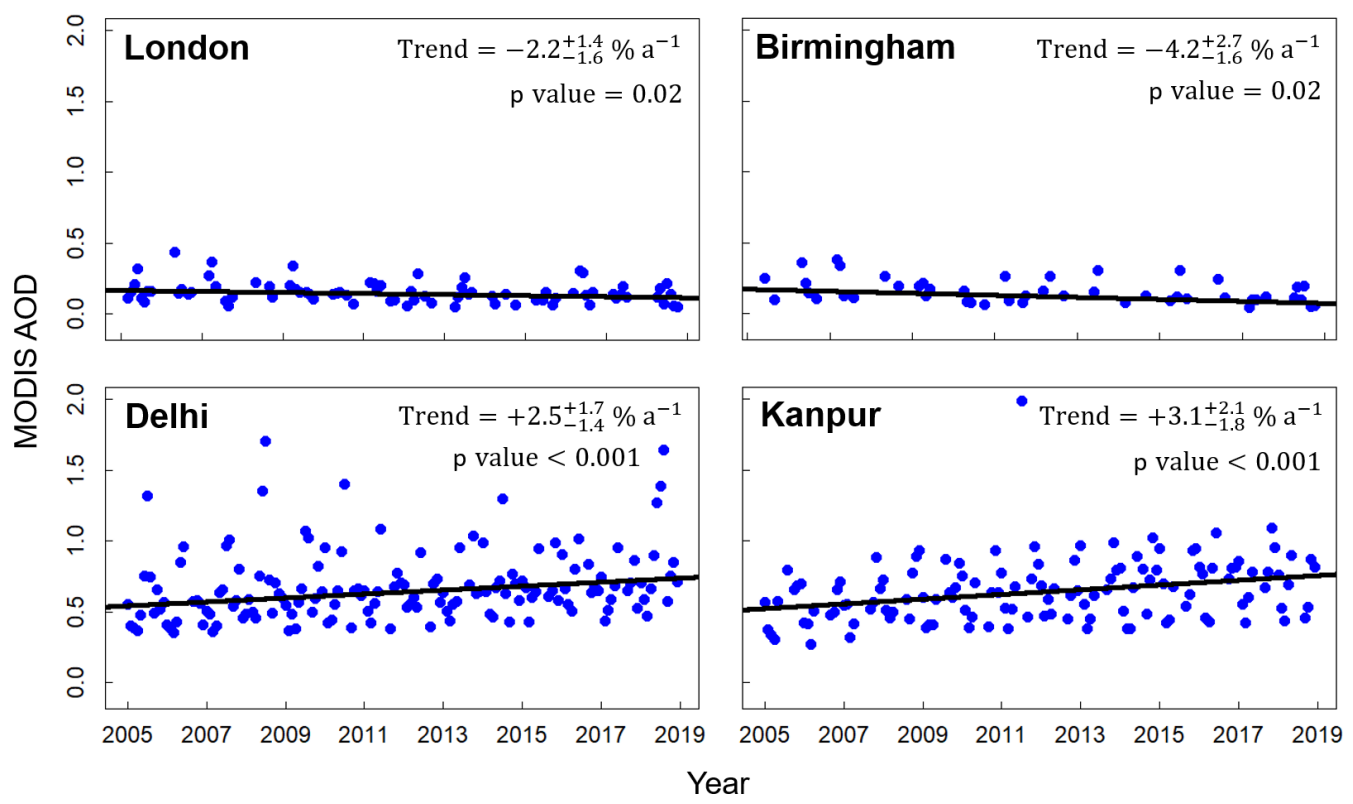

Figure 10. Time series of MODIS AOD for London, Birmingham, Delhi, and Kanpur. Points are city-average monthly means. Black lines are trends obtained with the Theil-Sen single median estimator. Values inset are annual trends and $p$ values. Absolute errors on the trends are the $95 \%$ CI.

ing. This would have implications for formation of secondary organic aerosols (SOAs) contributing to $\mathrm{PM}_{2.5}$, the radical $\left(\mathrm{HO}_{x}\right)$ budget that includes a large contribution from $\mathrm{HCHO}$ photolysis, and formation of surface ozone that is VOClimited in London.

Data availability. Corrected hourly $\mathrm{NO}_{2}$ data for Delhi and Kanpur are available at https://github.com/karnvoh/India-NO2-data (last access: 6 April 2020) and https://doi.org/10.5281/zenodo.4696252 (Vohra, 2021). Data from IIT Kanpur can be obtained by contacting Sachchida N. Tripathi (snt@iitk.ac.in). Data for Birmingham not publicly available can be obtained by request from the Birmingham City Council. IASI $\mathrm{NH}_{3}$ data were provided by Martin Van Damme, Lieven Clarisse, and Pierre-F. Coheur and are now available at https://iasi.aeris-data.fr/nh3/ (ULB, 2021).

Author contributions. KV analysed and interpreted the data and prepared the manuscript, and EAM assisted in the writing and provided supervisory guidance, with co-supervision from WJB. LK provided data analysis and usage guidance. ShS derived the relationship between hourly $\mathrm{PM}_{10}$ and $\mathrm{PM}_{2.5}$ for Birmingham. Observations are from RS, AG, and SNT for the surface site in Kanpur and from MVD, LC, and PFC for IASI $\mathrm{NH}_{3}$.

Competing interests. The authors declare that they have no conflict of interest.
Acknowledgements. We thank the NERC Field Spectroscopy Facility, principal investigators, and their staff for establishing and maintaining the AERONET sites at Kanpur and Chilbolton and Peter Porter from Birmingham City Council for providing the surface network data for Birmingham. URLs and DOIs (if available) of the data used in this study are given in Sect. 2.

Financial support. This work was funded by a University of Birmingham Global Challenges Studentship awarded to Karn Vohra, a NERC/EPSRC grant (EP/R513465/1) awarded to Eloise A. Marais, a Chevening Scholarship from the Foreign and Commonwealth Office and partner organisations awarded to Shannen Suckra, and a DBT grant (BT/IN/UK/APHH/41/KB/2016-17) and CPCB grant (AQM/Source apportionment_EPC Project/2017) awarded to Sachchida N. Tripathi. ULB research by Martin Van Damme, Lieven Clarisse, and Pierre-F. Coheur was supported by the Belgian State Federal Office for Scientific, Technical and Cultural Affairs (Prodex arrangement IASI.FLOW).

Review statement. This paper was edited by Michel Van Roozendael and reviewed by Richard Pope and two anonymous referees.

\section{References}

Aas, W., Mortier, A., Bowersox, V., Cherian, R., Faluvegi, G., Fagerli, H., Hand, J., Klimont, Z., Galy-Lacaux, C., Lehmann, C. M. B., Myhre, C. L., Myhre, G., Olivie, D., Sato, K., Quaas, J., Rao, P. S. P., Schulz, M., Shindell, D., Skeie, R. B., Stein, A., Takemura, T., Tsyro, S., Vet, R., and Xu, X. B.: Global 
and regional trends of atmospheric sulfur, Sci. Rep.-UK, 9, 953, https://doi.org/10.1038/s41598-018-37304-0, 2019.

Anenberg, S. C., Achakulwisut, P., Brauer, M., Moran, D., Apte, J. S., and Henze, D. K.: Particulate matter-attributable mortality and relationships with carbon dioxide in 250 urban areas worldwide, Sci. Rep.-UK, 9, 11552, https://doi.org/10.1038/s41598019-48057-9, 2019.

Barnes, J. H., Hayes, E. T., Chatterton, T. J., and Longhurst, J. W. S.: Policy disconnect: A critical review of UK air quality policy in relation to EU and LAQM responsibilities over the last 20 years, Environ. Sci. Policy, 85, 28-39, https://doi.org/10.1016/j.envsci.2018.03.024, 2018.

Bilal, M., Qiu, Z. F., Campbell, J. R., Spak, S. N., Shen, X. J., and Nazeer, M.: A New MODIS C6 Dark Target and Deep Blue Merged Aerosol Product on a $3 \mathrm{~km}$ Spatial Grid, Remote Sens.Basel, 10, 463, https://doi.org/10.3390/rs10030463, 2018.

Boersma, K. F., Eskes, H. J., and Brinksma, E. J.: Error analysis for tropospheric $\mathrm{NO}_{2}$ retrieval from space, J. Geophys. Res.-Atmos., 109, D04311, https://doi.org/10.1029/2003jd003962, 2004.

Boersma, K. F., Jacob, D. J., Trainic, M., Rudich, Y., DeSmedt, I., Dirksen, R., and Eskes, H. J.: Validation of urban $\mathrm{NO}_{2}$ concentrations and their diurnal and seasonal variations observed from the SCIAMACHY and OMI sensors using in situ surface measurements in Israeli cities, Atmos. Chem. Phys., 9, 3867-3879, https://doi.org/10.5194/acp-9-3867-2009, 2009.

Brauer, M., Freedman, G., Frostad, J., van Donkelaar, A., Martin, R. V., Dentener, F., van Dingenen, R., Estep, K., Amini, H., Apte, J. S., Balakrishnan, K., Barregard, L., Broday, D., Feigin, V., Ghosh, S., Hopke, P. K., Knibbs, L. D., Kokubo, Y., Liu, Y., Ma, S. F., Morawska, L., Sangrador, J. L. T., Shaddick, G., Anderson, H. R., Vos, T., Forouzanfar, M. H., Burnett, R. T., and Cohen, A.: Ambient Air Pollution Exposure Estimation for the Global Burden of Disease 2013, Environ. Sci. Technol., 50, 7988, https://doi.org/10.1021/acs.est.5b03709, 2016.

Carnell, E., Vieno, M., Vardoulakis, S., Beck, R., Heaviside, C., Tomlinson, S., Dragosits, U., Heal, M. R., and Reis, S.: Modelling public health improvements as a result of air pollution control policies in the UK over four decades - 1970 to 2010, Environ. Res. Lett., 14, 074001, https://doi.org/10.1088/17489326/ab1542, 2019.

Carslaw, D. C., Beevers, S. D., Westmoreland, E., Williams, M. L., Tate, J. E., Murrells, T., Stedman, J., Li, Y., Grice, S., Kent, A., and Tsagatakis, I.: Trends in $\mathrm{NO}_{x}$ and $\mathrm{NO}_{2}$ emissions and ambient measurements in the UK, available at: https://uk-air.defra.gov.uk/assets/documents/reports/cat05/ 1108251149_110718_AQ0724_Final_report.pdf (last access: 16 January 2020) 2011.

Carslaw, D. C., Murrells, T. P., Andersson, J., and Keenan, M.: Have vehicle emissions of primary $\mathrm{NO}_{2}$ peaked?, Faraday Discuss., 189, 439-454, https://doi.org/10.1039/c5fd00162e, 2016.

Castell, N., Dauge, F. R., Schneider, P., Vogt, M., Lerner, U., Fishbain, B., Broday, D., and Bartonova, A.: Can commercial low-cost sensor platforms contribute to air quality monitoring and exposure estimates?, Environ. Int., 99, 293-302, https://doi.org/10.1016/j.envint.2016.12.007, 2017.

Chalilyakunnel, S., Millet, D. B., and Chen, X.: Constraining emissions of volatile organic compounds over the Indian subcontinent using spacebased formaldehyde measurements, J. Geophys. Res., 124, 10525-10545, https://doi.org/10.1029/2019JD031262, 2019.

Choi, S., Lamsal, L. N., Follette-Cook, M., Joiner, J., Krotkov, N. A., Swartz, W. H., Pickering, K. E., Loughner, C. P., Appel, W., Pfister, G., Saide, P. E., Cohen, R. C., Weinheimer, A. J., and Herman, J. R.: Assessment of $\mathrm{NO}_{2}$ observations during DISCOVERAQ and KORUS-AQ field campaigns, Atmos. Meas. Tech., 13, 2523-2546, https://doi.org/10.5194/amt-13-2523-2020, 2020.

Clarisse, L., Shephard, M. W., Dentener, F., Hurtmans, D., CadyPereira, K., Karagulian, F., Van Damme, M., Clerbaux, C., and Coheur, P. F.: Satellite monitoring of ammonia: A case study of the San Joaquin Valley, J. Geophys. Res.-Atmos., 115, D13302, https://doi.org/10.1029/2009jd013291, 2010.

CPCB: Central Pollution Control Board, India, Protocol for Data Transmission from CAAQM Stations Existing as on Date, available at: https://app.cpcbccr.com/ccr_docs/Protocol_ CAAQM.pdf (last access: 8 March 2020), 2015.

Crilley, L. R., Bloss, W. J., Yin, J., Beddows, D. C. S., Harrison, R. M., Allan, J. D., Young, D. E., Flynn, M., Williams, P., Zotter, P., Prevot, A. S. H., Heal, M. R., Barlow, J. F., Halios, C. H., Lee, J. D., Szidat, S., and Mohr, C.: Sources and contributions of wood smoke during winter in London: assessing local and regional influences, Atmos. Chem. Phys., 15, 3149-3171, https://doi.org/10.5194/acp-15-3149-2015, 2015.

Crilley, L. R., Lucarelli, F., Bloss, W. J., Harrison, R. M., Beddows, D. C., Calzolai, G., Nava, S., Valli, G., Bernardoni, V., and Vecchi, R.: Source apportionment of fine and coarse particles at a roadside and urban background site in London during the 2012 summer ClearfLo campaign, Environ. Pollut., 220, 766-778, https://doi.org/10.1016/j.envpol.2016.06.002, 2017.

Cusworth, D. H., Mickley, L. J., Sulprizio, M. P., Liu, T. J., Marlier, M. E., DeFries, R. S., Guttikunda, S. K., and Gupta, P.: Quantifying the influence of agricultural fires in northwest India on urban air pollution in Delhi, India, Environ. Res. Lett., 13, 044018, https://doi.org/10.1088/1748-9326/aab303, 2018.

Dammers, E., Palm, M., Van Damme, M., Vigouroux, C., Smale, D., Conway, S., Toon, G. C., Jones, N., Nussbaumer, E., Warneke, T., Petri, C., Clarisse, L., Clerbaux, C., Hermans, C., Lutsch, E., Strong, K., Hannigan, J. W., Nakajima, H., Morino, I., Herrera, B., Stremme, W., Grutter, M., Schaap, M., Wichink Kruit, R. J., Notholt, J., Coheur, P.-F., and Erisman, J. W.: An evaluation of IASI-NH3 with ground-based Fourier transform infrared spectroscopy measurements, Atmos. Chem. Phys., 16, 10351-10368, https://doi.org/10.5194/acp-16-10351-2016, 2016.

Dammers, E., McLinden, C. A., Griffin, D., Shephard, M. W., Van Der Graaf, S., Lutsch, E., Schaap, M., Gainairu-Matz, Y., Fioletov, V., Van Damme, M., Whitburn, S., Clarisse, L., CadyPereira, K., Clerbaux, C., Coheur, P. F., and Erisman, J. W.: $\mathrm{NH}_{3}$ emissions from large point sources derived from CrIS and IASI satellite observations, Atmos. Chem. Phys., 19, 12261-12293, https://doi.org/10.5194/acp-19-12261-2019, 2019.

Datameet India: Community data, available at: https://github. com/datameet/maps/tree/master/Country (last access: 12 March 2021), 2018

David, L. M., Ravishankara, A. R., Kodros, J. K., Venkataraman, C., Sadavarte, P., Pierce, J. R., Chaliyakunnel, S., and Millet, D. B.: Aerosol Optical Depth Over India, J. Geophys. Res.-Atmos., 123, 3688-3703, https://doi.org/10.1002/2017jd027719, 2018. 
De Smedt, I., Stavrakou, T., Muller, J. F., van der A, R. J., and Van Roozendael, M.: Trend detection in satellite observations of formaldehyde tropospheric columns, Geophys. Res. Lett., 37, L18808, https://doi.org/10.1029/2010g1044245, 2010.

De Smedt, I., van Geffen, J., Richter, A., Beirle, S., Yu, H., Vlietinck, J., Roozendael, M. V., van der A, R., Lorente, A., Scanlon, T., Compernolle, S., Wagner, T., Eskes, H., and Boersma, F.: Product User Guide for HCHO (Version 1.0), https://doi.org/10.18758/71021031, 2017.

De Smedt, I., Theys, N., Yu, H., Danckaert, T., Lerot, C., Compernolle, S., Van Roozendael, M., Richter, A., Hilboll, A., Peters, E., Pedergnana, M., Loyola, D., Beirle, S., Wagner, T., Eskes, H., van Geffen, J., Boersma, K. F., and Veefkind, P.: Algorithm theoretical baseline for formaldehyde retrievals from S5P TROPOMI and from the QA4ECV project, Atmos. Meas. Tech., 11, 23952426, https://doi.org/10.5194/amt-11-2395-2018, 2018.

Defra: Department for Environment Food \& Rural Affairs, United Kingdom, Emissions of air pollutants in the UK, 1970 to 2017, available at: https://assets.publishing.service. gov.uk/government/uploads/system/uploads/attachment_data/ file/778483/Emissions_of_air_pollutants_1990_2017.pdf, last access: 20 December 2019a.

Defra: Department for Environment Food \& Rural Affairs, United Kingdom, Clean Air Strategy, available at: https://assets. publishing.service.gov.uk/government/uploads/system/uploads/ attachment_data/file/770715/clean-air-strategy-2019.pdf (last access: 8 March 2020), 2019b.

Duncan, B. N., Prados, A. I., Lamsal, L. N., Liu, Y., Streets, D. G., Gupta, P., Hilsenrath, E., Kahn, R. A., Nielsen, J. E., Beyersdorf, A. J., Burton, S. P., Fiore, A. M., Fishman, J., Henze, D. K., Hostetler, C. A., Krotkov, N. A., Lee, P., Lin, M. Y., Pawson, S., Pfister, G., Pickering, K. E., Pierce, R. B., Yoshida, Y., and Ziemba, L. D.: Satellite data of atmospheric pollution for US air quality applications: Examples of applications, summary of data end-user resources, answers to FAQs, and common mistakes to avoid, Atmos. Environ., 94, 647-662, https://doi.org/10.1016/j.atmosenv.2014.05.061, 2014.

Dunlea, E. J., Herndon, S. C., Nelson, D. D., Volkamer, R. M., San Martini, F., Sheehy, P. M., Zahniser, M. S., Shorter, J. H., Wormhoudt, J. C., Lamb, B. K., Allwine, E. J., Gaffney, J. S., Marley, N. A., Grutter, M., Marquez, C., Blanco, S., Cardenas, B., Retama, A., Ramos Villegas, C. R., Kolb, C. E., Molina, L. T., and Molina, M. J.: Evaluation of nitrogen dioxide chemiluminescence monitors in a polluted urban environment, Atmos. Chem. Phys., 7, 2691-2704, https://doi.org/10.5194/acp-7-26912007, 2007.

Eck, T. F., Holben, B. N., Reid, J. S., Dubovik, O., Smirnov, A., O’Neill, N. T., Slutsker, I., and Kinne, S.: Wavelength dependence of the optical depth of biomass burning, urban, and desert dust aerosols, J. Geophys. Res.-Atmos., 104, 3133331349, https://doi.org/10.1029/1999jd900923, 1999.

Fioletov, V. E., McLinden, C. A., Krotkov, N., Li, C., Joiner, J., Theys, N., Carn, S., and Moran, M. D.: A global catalogue of large SO2 sources and emissions derived from the Ozone Monitoring Instrument, Atmos. Chem. Phys., 16, 11497-11519, https://doi.org/10.5194/acp-16-11497-2016, 2016.

Fishman, J., Bowman, K. W., Burrows, J. P., Richter, A., Chance, K. V., Edwards, D. P., Martin, R. V., Morris, G. A., Pierce, R. B., Ziemke, J. R., Al-Saadi, J. A., Creilson, J. K., Schaack,
T. K., and Thompson, A. M.: Remote sensing of tropospheric pollution from space, B. Am. Meteorol. Soc., 89, 805-821, https://doi.org/10.1175/2008bams2526.1, 2008.

Fontaras, G., Franco, V., Dilara, P., Martini, G., and Manfredi, U.: Development and review of Euro 5 passenger car emission factors based on experimental results over various driving cycles, Sci. Total Environ., 468, 1034-1042, https://doi.org/10.1016/j.scitotenv.2013.09.043, 2014.

Fuller, G. W., Tremper, A. H., Baker, T. D., Yttri, K. E., and Butterfield, D.: Contribution of wood burning to $\mathrm{PM}_{10}$ in London, Atmos. Environ., 87, 87-94, https://doi.org/10.1016/j.atmosenv.2013.12.037, 2014.

GADM Data: available atL https://gadm.org/ (last access: 12 March 2021), 2018.

Gaur, A., Tripathi, S. N., Kanawade, V. P., Tare, V., and Shukla, S. P.: Four-year measurements of trace gases $\left(\mathrm{SO}_{2}, \mathrm{NO}_{x}, \mathrm{CO}\right.$, and $\mathrm{O}_{3}$ ) at an urban location, Kanpur, in Northern India, J. Atmos. Chem., 71, 283-301, https://doi.org/10.1007/s10874-014-9295$8,2014$.

Georgoulias, A. K., Alexandri, G., Kourtidis, K. A., Lelieveld, J., Zanis, P., Pöschl, U., Levy, R., Amiridis, V., Marinou, E., and Tsikerdekis, A.: Spatiotemporal variability and contribution of different aerosol types to the aerosol optical depth over the Eastern Mediterranean, Atmos. Chem. Phys., 16, 13853-13884, https://doi.org/10.5194/acp-16-13853-2016, 2016.

Georgoulias, A. K., van der A, R. J., Stammes, P., Boersma, K. F., and Eskes, H. J.: Trends and trend reversal detection in 2 decades of tropospheric $\mathrm{NO}_{2}$ satellite observations, Atmos. Chem. Phys., 19, 6269-6294, https://doi.org/10.5194/acp19-6269-2019, 2019.

Ghosh, S., Gupta, T., Rastogi, N., Gaur, A., Misra, A., Tripathi, S. N., Paul, D., Tare, V., Prakash, O., Bhattu, D., Dwivedi, A. K., Kaul, D. S., Dalai, R., and Mishra, S. K.: Chemical Characterization of Summertime Dust Events at Kanpur: Insight into the Sources and Level of Mixing with Anthropogenic Emissions, Aerosol Air Qual. Res., 14, 879-891, https://doi.org/10.4209/aaqr.2013.07.0240, 2014.

Giles, D. M., Sinyuk, A., Sorokin, M. G., Schafer, J. S., Smirnov, A., Slutsker, I., Eck, T. F., Holben, B. N., Lewis, J. R., Campbell, J. R., Welton, E. J., Korkin, S. V., and Lyapustin, A. I.: Advancements in the Aerosol Robotic Network (AERONET) Version 3 database - automated near-real-time quality control algorithm with improved cloud screening for Sun photometer aerosol optical depth (AOD) measurements, Atmos. Meas. Tech., 12, 169209, https://doi.org/10.5194/amt-12-169-2019, 2019.

Govt. of Delhi: Planning Department, Delhi, Economic Survey of Delhi, 2018-2019, 2019.

Govt. of India: Ministry of Road Transport and Highways, India, Notification, available at: http://egazette.nic.in/WriteReadData/ 2016/168300.pdf (last access: 16 January 2020), 2016.

Govt. of India: Ministry of Environment Forest \& Climate Change, India, National Clean Air Program, 2019.

Grange, S. K., Lewis, A. C., Moller, S. J., and Carslaw, D. C.: Lower vehicular primary emissions of $\mathrm{NO}_{2}$ in Europe than assumed in policy projections, Nat. Geosci., 10, 914-918, https://doi.org/10.1038/s41561-017-0009-0, 2017.

Gupta, P., Remer, L. A., Levy, R. C., and Mattoo, S.: Validation of MODIS $3 \mathrm{~km}$ land aerosol optical depth from NASA's EOS 
Terra and Aqua missions, Atmos. Meas. Tech., 11, 3145-3159, https://doi.org/10.5194/amt-11-3145-2018, 2018.

Guttikunda, S. K. and Jawahar, P.: Atmospheric emissions and pollution from the coal-fired thermal power plants in India, Atmos. Environ., 92, 449-460, https://doi.org/10.1016/j.atmosenv.2014.04.057, 2014.

Harrison, R. G., Nicoll, K. A., Marlton, G. J., Ryder, C. L., and Bennett, A. J., Saharan dust plume charging observed over the UK, Environ. Res. Lett., 13, https://doi.org/10.1088/17489326/aabcd9, 2018.

Harrison, R. M. and Beddows, D. C.: Efficacy of Recent Emissions Controls on Road Vehicles in Europe and Implications for Public Health, Sci. Rep.-UK, 7, 1152, https://doi.org/10.1038/s41598017-01135-2, 2017.

Heal, M. R., O’Donoghue, M. A., and Cape, J. N.: Overestimation of urban nitrogen dioxide by passive diffusion tubes: a comparative exposure and model study, Atmos. Environ., 33, 513-524, https://doi.org/10.1016/S1352-2310(98)00290-8, 1999.

Hilboll, A., Richter, A., and Burrows, J. P., Long-term changes of tropospheric $\mathrm{NO}_{2}$ over megacities derived from multiple satellite instruments, Atmos. Chem. Phys., 13, 4145-4169, https://doi.org/10.5194/acp-13-4145-2013, 2013.

Holben, B. N., Eck, T. F., Slutsker, I., Tanre, D., Buis, J. P., Setzer, A., Vermote, E., Reagan, J. A., Kaufman, Y. J., Nakajima, T., Lavenu, F., Jankowiak, I., and Smirnov, A.: AERONET - A federated instrument network and data archive for aerosol characterization, Remote Sens. Environ., 66, 1-16, https://doi.org/10.1016/S0034-4257(98)00031-5, 1998.

Jethva, H., Torres, O., Field, R. D., Lyapustin, A., Gautam, R., and Kayetha, V., Connecting Crop Productivity, Residue Fires, and Air Quality over Northern India, Sci. Rep.-UK, 9, 16594, https://doi.org/10.1038/s41598-019-52799-x, 2019.

Jones, N. B., Riedel, K., Allan, W., Wood, S., Palmer, P. I., Chance, K., and Notholt, J.: Long-term tropospheric formaldehyde concentrations deduced from ground-based fourier transform solar infrared measurements, Atmos. Chem. Phys., 9, 7131-7142, https://doi.org/10.5194/acp-9-7131-2009, 2009.

Kaskaoutis, D. G., Singh, R. P., Gautam, R., Sharma, M., Kosmopoulos, P. G., and Tripathi, S. N.: Variability and trends of aerosol properties over Kanpur, northern India using AERONET data (2001-10), Environ. Res. Lett., 7, 024003, https://doi.org/10.1088/1748-9326/7/2/024003, 2012.

Kaufman, Y. J.: Aerosol Optical-Thickness and Atmospheric Path Radiance, J. Geophys. Res.-Atmos., 98, 2677-2692, https://doi.org/10.1029/92jd02427, 1993.

Kenagy, H. S., Sparks, T. L., Ebben, C. J., Wooldrige, P. J., Lopez-Hilfiker, F. D., Lee, B. H., Thornton, J. A., McDuffie, E. E., Fibiger, D. L., Brown, S. S., Montzka, D. D., Weinheimer, A. J., Schroder, J. C., Campuzano-Jost, P., Day, D. A., Jimenez, J. L., Dibb, J. E., Campos, T., Shah, V., Jaegle, L., and Cohen, R. C.: $\mathrm{NO}_{x}$ Lifetime and $\mathrm{NO}_{y}$ Partitioning During WINTER, J. Geophys. Res.-Atmos., 123, 9813-9827, https://doi.org/10.1029/2018jd028736, 2018.

Kim, S. W., Heckel, A., McKeen, S. A., Frost, G. J., Hsie, E. Y., Trainer, M. K., Richter, A., Burrows, J. P., Peckham, S. E., and Grell, G. A.: Satellite-observed US power plant $\mathrm{NO}_{x}$ emission reductions and their impact on air quality, Geophys. Res. Lett., 33, L22812, https://doi.org/10.1029/2006g1027749, 2006.
Klimont, Z., Smith, S. J., and Cofala, J.: The last decade of global anthropogenic sulfur dioxide: 2000-2011 emissions, Environ. Res. Lett., 8, 014003, https://doi.org/10.1088/17489326/8/1/014003, 2013.

Kotthaus, S. and Grimmond, C. S. B.: Atmospheric boundary-layer characteristics from ceilometer measurements. Part 2: Application to London's urban boundary layer, Q. J. Roy. Meteor. Soc., 144, 1511-1524, https://doi.org/10.1002/qj.3298, 2018.

Kramer, L. J., Leigh, R. J., Remedios, J. J., and Monks, P. S.: Comparison of OMI and ground-based in situ and MAX-DOAS measurements of tropospheric nitrogen dioxide in an urban area, J. Geophys. Res.-Atmos., 113, D16S39, https://doi.org/10.1029/2007jd009168, 2008.

Krotkov, N. A., Lamsal, L. N., Celarier, E. A., Swartz, W. H., Marchenko, S. V., Bucsela, E. J., Chan, K. L., Wenig, M., and Zara, M.: The version 3 OMI NO2 standard product, Atmos. Meas. Tech., 10, 3133-3149, https://doi.org/10.5194/amt10-3133-2017, 2017.

Lamsal, L. N., Martin, R. V., van Donkelaar, A., Celarier, E. A., Bucsela, E. J., Boersma, K. F., Dirksen, R., Luo, C., and Wang, Y.: Indirect validation of tropospheric nitrogen dioxide retrieved from the OMI satellite instrument: Insight into the seasonal variation of nitrogen oxides at northern midlatitudes, J. Geophys. Res.-Atmos., 115, D05302, https://doi.org/10.1029/2009jd013351, 2010.

Lamsal, L. N., Martin, R. V., Padmanabhan, A., van Donkelaar, A., Zhang, Q., Sioris, C. E., Chance, K., Kurosu, T. P., and Newchurch, M. J.: Application of satellite observations for timely updates to global anthropogenic $\mathrm{NO}_{x}$ emission inventories, Geophys. Res. Lett., 38, L05810, https://doi.org/10.1029/2010gl046476, 2011.

Landrigan, P. J., Fuller, R., Acosta, N. J. R., Adeyi, O., Arnold, R., Basu, N., Balde, A. B., Bertollini, R., Bose-O'Reilly, S., Boufford, J. I., Breysse, P. N., Chiles, T., Mahidol, C., CollSeck, A. M., Cropper, M. L., Fobil, J., Fuster, V., Greenstone, M., Haines, A., Hanrahan, D., Hunter, D., Khare, M., Krupnick, A., Lanphear, B., Lohani, B., Martin, K., Mathiasen, K. V., McTeer, M. A., Murray, C. J. L., Ndahimananjara, J. D., Perera, F., Potocnik, J., Preker, A. S., Ramesh, J., Rockstrom, J., Salinas, C., Samson, L. D., Sandilya, K., Sly, P. D., Smith, K. R., Steiner, A., Stewart, R. B., Suk, W. A., van Schayck, O. C. P., Yadama, G. N., Yumkella, K., and Zhong, M.: The Lancet Commission on pollution and health, Lancet, 391, 462512, https://doi.org/10.1016/S0140-6736(17)32345-0, 2018.

Langford, B., Nemitz, E., House, E., Phillips, G. J., Famulari, D., Davison, B., Hopkins, J. R., Lewis, A. C., and Hewitt, C. N.: Fluxes and concentrations of volatile organic compounds above central London, UK, Atmos. Chem. Phys., 10, 627-645, https://doi.org/10.5194/acp-10-627-2010, 2010.

Levy, R. C., Remer, L. A., and Dubovik, O.: Global aerosol optical properties and application to Moderate Resolution Imaging Spectroradiometer aerosol retrieval over land, J. Geophys. Res.Atmos., 112, D13210, https://doi.org/10.1029/2006jd007815, 2007.

Levy, R. C., Remer, L. A., Kleidman, R. G., Mattoo, S., Ichoku, C., Kahn, R., and Eck, T. F.: Global evaluation of the Collection 5 MODIS dark-target aerosol products over land, Atmos. Chem. Phys., 10, 10399-10420, https://doi.org/10.5194/acp-10-103992010, 2010. 
Levy, R. C., Mattoo, S., Munchak, L. A., Remer, L. A., Sayer, A. M., Patadia, F., and Hsu, N. C.: The Collection 6 MODIS aerosol products over land and ocean, Atmos. Meas. Tech., 6, 29893034, https://doi.org/10.5194/amt-6-2989-2013, 2013.

Li, Q., Li, C. C., and Mao, J. T.: Evaluation of Atmospheric Aerosol Optical Depth Products at Ultraviolet Bands Derived from MODIS Products, Aerosol Sci. Tech., 46, 1025-1034, https://doi.org/10.1080/02786826.2012.687475, 2012.

Lin, J.-T., Liu, M.-Y., Xin, J.-Y., Boersma, K. F., Spurr, R., Martin, R., and Zhang, Q.: Influence of aerosols and surface reflectance on satellite $\mathrm{NO}_{2}$ retrieval: seasonal and spatial characteristics and implications for $\mathrm{NO}_{x}$ emission constraints, Atmos. Chem. Phys., 15, 11217-11241, https://doi.org/10.5194/acp-15-112172015, 2015.

Liu, T. J., Marlier, M. E., DeFries, R. S., Westervelt, D. M., Xia, K. R., Fiore, A. M., Mickley, L. J., Cusworth, D. H., and Milly, G.: Seasonal impact of regional outdoor biomass burning on air pollution in three Indian cities: Delhi, Bengaluru, and Pune, Atmos. Environ., 172, 83-92, https://doi.org/10.1016/j.atmosenv.2017.10.024, 2018.

Lyons, R., Doherty, R., Reay, D., and Shackley, S.: Legal but lethal: Lessons from $\mathrm{NO}_{2}$ related mortality in a city compliant with EU limit value, Atmos. Pollut. Res., 11, 43-50, https://doi.org/10.1016/j.apr.2020.02.016, 2020.

Malley, C. S., Braban, C. F., Dumitrean, P., Cape, J. N., and Heal, M. R.: The impact of speciated VOCs on regional ozone increment derived from measurements at the UK EMEP supersites between 1999 and 2012, Atmos. Chem. Phys., 15, 8361-8380, https://doi.org/10.5194/acp-15-8361-2015, 2015.

Malley, C. S., Heal, M. R., Braban, C. F., Kentisbeer, J., Leeson, S. R., Malcolm, H., Lingard, J. J. N., Ritchie, S., Maggs, R., Beccaceci, S., Quincey, P., Brown, R. J. C., and Twigg, M. M.: The contributions to long-term health-relevant particulate matter at the UK EMEP supersites between 2010 and 2013: Quantifying the mitigation challenge, Environ. Int., 95, 98-111, https://doi.org/10.1016/j.envint.2016.08.005, 2016.

Marais, E. A., Jacob, D. J., Kurosu, T. P., Chance, K., Murphy, J. G., Reeves, C., Mills, G., Casadio, S., Millet, D. B., Barkley, M. P., Paulot, F., and Mao, J.: Isoprene emissions in Africa inferred from OMI observations of formaldehyde columns, Atmos. Chem. Phys., 12, 6219-6235, https://doi.org/10.5194/acp12-6219-2012, 2012.

Marais, E. A., Jacob, D. J., Wecht, K., Lerot, C., Zhang, L., Yu, K., Kurosu, T. P., Chance, K., and Sauvage, B.: Anthropogenic emissions in Nigeria and implications for atmospheric ozone pollution: A view from space, Atmos. Environ., 99, 32-40, https://doi.org/10.1016/j.atmosenv.2014.09.055, 2014a.

Marais, E. A., Jacob, D. J., Guenther, A., Chance, K., Kurosu, T. P., Murphy, J. G., Reeves, C. E., and Pye, H. O. T.: Improved model of isoprene emissions in Africa using Ozone Monitoring Instrument (OMI) satellite observations of formaldehyde: implications for oxidants and particulate matter, Atmos. Chem. Phys., 14, 7693-7703, https://doi.org/10.5194/acp-14-7693-2014, 2014b.

Martin, R. V., Jacob, D. J., Chance, K., Kurosu, T. P., Palmer, P. I., and Evans, M. J.: Global inventory of nitrogen oxide emissions constrained by space-based observations of $\mathrm{NO}_{2}$ columns, J. Geophys. Res.-Atmos., 108, 4537, https://doi.org/10.1029/2003jd003453, 2003.
McPhetres, A. and Aggarwal, S.: An Evaluation of MODISRetrieved Aerosol Optical Depth over AERONET Sites in Alaska, Remote Sens.-Basel, 10, 1384, https://doi.org/10.3390/rs10091384, 2018.

Mhawish, A., Banerjee, T., Broday, D. M., Misra, A., and Tripathi, S. N.: Evaluation of MODIS Collection 6 aerosol retrieval algorithms over Indo-Gangetic Plain: Implications of aerosols types and mass loading, Remote Sens. Environ., 201, 297-313, https://doi.org/10.1016/j.rse.2017.09.016, 2017.

Miller, S. M., Matross, D. M., Andrews, A. E., Millet, D. B., Longo, M., Gottlieb, E. W., Hirsch, A. I., Gerbig, C., Lin, J. C., Daube, B. C., Hudman, R. C., Dias, P. L. S., Chow, V. Y., and Wofsy, S. C.: Sources of carbon monoxide and formaldehyde in North America determined from high-resolution atmospheric data, Atmos. Chem. Phys., 8, 7673-7696, https://doi.org/10.5194/acp-87673-2008, 2008.

Millet, D. B., Jacob, D. J., Turquety, S., Hudman, R. C., Wu, S. L., Fried, A., Walega, J., Heikes, B. G., Blake, D. R., Singh, H. B., Anderson, B. E., and Clarke, A. D.: Formaldehyde distribution over North America: Implications for satellite retrievals of formaldehyde columns and isoprene emission, J. Geophys. Res.Atmos., 111, D24S02, https://doi.org/10.1029/2005jd006853, 2006.

Munchak, L. A., Levy, R. C., Mattoo, S., Remer, L. A., Holben, B. N., Schafer, J. S., Hostetler, C. A., and Ferrare, R. A.: MODIS $3 \mathrm{~km}$ aerosol product: applications over land in an urban/suburban region, Atmos. Meas. Tech., 6, 1747-1759, https://doi.org/10.5194/amt-6-1747-2013, 2013.

Nagar, P. K., Sharma, M., and Das, D.: A new method for trend analyses in $\mathrm{PM}_{10}$ and impact of crop residue burning in Delhi, Kanpur and Jaipur, India, Urban Clim., 27, 193-203, https://doi.org/10.1016/j.uclim.2018.12.003, 2019.

Nakoudi, K., Giannakaki, E., Dandou, A., Tombrou, M., and Komppula, M.: Planetary boundary layer height by means of lidar and numerical simulations over New Delhi, India, Atmos. Meas. Tech., 12, 2595-2610, https://doi.org/10.5194/amt12-2595-2019, 2019.

Ots, R., Heal, M. R., Young, D. E., Williams, L. R., Allan, J. D., Nemitz, E., Di Marco, C., Detournay, A., Xu, L., Ng, N. L., Coe, H., Herndon, S. C., Mackenzie, I. A., Green, D. C., Kuenen, J. J. P., Reis, S., and Vieno, M.: Modelling carbonaceous aerosol from residential solid fuel burning with different assumptions for emissions, Atmos. Chem. Phys., 18, 4497-4518, https://doi.org/10.5194/acp-18-4497-2018, 2018.

Parkhi, N., Chate, D., Ghude, S. D., Peshin, S., Mahajan, A., Srinivas, R., Surendran, D., Ali, K., Singh, S., Trimbake, H., and Beig, G.: Large inter annual variation in air quality during the annual festival "Diwali" in an Indian megacity, J. Environ. Sci.-China, 43, 265-272, https://doi.org/10.1016/j.jes.2015.08.015, 2016.

Pathania, R., Phadke, P., Gupta, R. K., and Ramanathan, S.: Centre for Science and Environment, New Delhi, OffTarget Status of Thermal Power Stations in Delhi NCR, available at: http://www.indiaenvironmentportal.org.in/files/file/ Off-Target---Status-of-Power-Stations-Report.pdf (last access: 16 January 2020), 2018.

Paulot, F., Paynter, D., Ginoux, P., Naik, V., Whitburn, S., Van Damme, M., Clarisse, L., Coheur, P. F., and Horowitz, L. W.: Gas-aerosol partitioning of ammonia in biomass burning plumes: Implications for the interpretation of space- 
borne observations of ammonia and the radiative forcing of ammonium nitrate, Geophys. Res. Lett., 44, 8084-8093, https://doi.org/10.1002/2017g1074215, 2017.

Petrenko, M., Ichoku, C., and Leptoukh, G.: Multi-sensor Aerosol Products Sampling System (MAPSS), Atmos. Meas. Tech., 5, 913-926, https://doi.org/10.5194/amt-5-913-2012, 2012.

Pope, R. J., Arnold, S. R., Chipperfield, M. P., Latter, B. G., Siddans, R., and Kerridge, B. J.: Widespread changes in UK air quality observed from space, Atmos. Sci. Lett., 19, e817, https://doi.org/10.1002/asl.817, 2018.

Ramachandran, S., Kedia, S., and Srivastava, R.: Aerosol optical depth trends over different regions of India, Atmos. Environ., 49, 338-347, https://doi.org/10.1016/j.atmosenv.2011.11.017, 2012.

Reed, C., Evans, M. J., Di Carlo, P., Lee, J. D., and Carpenter, L. J.: Interferences in photolytic NO2 measurements: explanation for an apparent missing oxidant?, Atmos. Chem. Phys., 16, 47074724, https://doi.org/10.5194/acp-16-4707-2016, 2016.

Remer, L. A., Kaufman, Y. J., Tanre, D., Mattoo, S., Chu, D. A., Martins, J. V., Li, R. R., Ichoku, C., Levy, R. C., Kleidman, R. G., Eck, T. F., Vermote, E., and Holben, B. N.: The MODIS aerosol algorithm, products, and validation, J. Atmos. Sci., 62, 947-973, https://doi.org/10.1175/Jas3385.1, 2005.

Remer, L. A., Mattoo, S., Levy, R. C., and Munchak, L. A.: MODIS $3 \mathrm{~km}$ aerosol product: algorithm and global perspective, Atmos. Meas. Tech., 6, 1829-1844, https://doi.org/10.5194/amt-6-18292013, 2013.

Richmond, B., Misra, A., Brown, P., Karagianni, E., Murrells, T., Pang, Y., Passant, N., Pepler, A., Stewart, R., Thistlethwaite, G., Turtle, L., Wakeling, D., Walker, C., Wiltshire, J., Hobson, M., Gibbs, M., Misselbrook, T., Dragosit, U., and Tomlinson, S.: Environment, United Kingdom, UK Informative Inventory Report (1990 to 2018), available at: https://uk-air.defra.gov.uk/assets/ documents/reports/cat07/2003131327_GB_IIR_2020_v1.0.pdf (last access: 20 December 2019), 2020.

Richter, A.: Nitrogen oxides in the troposphere - What have we learned from satellite measurements?, Erca: From the Human Dimensions of Global Environmental Change to the Observation of the Earth from Space, Vol 8, WOS:000268062600011, 2009.

Sahu, L. K., Yadav, R., and Pal, D.: Source identification of VOCs at an urban site of western India: Effect of marathon events and anthropogenic emissions, J. Geophys. Res.-Atmos., 121, 24162433, https://doi.org/10.1002/2015jd024454, 2016.

Sathe, Y., Kulkarni, S., Gupta, P., Kaginalkar, A., Islam, S., and Gargava, P.: Application of Moderate Resolution Imaging Spectroradiometer (MODIS) Aerosol Optical Depth (AOD) and Weather Research Forecasting (WRF) model meteorological data for assessment of fine particulate matter $\left(\mathrm{PM}_{2.5}\right)$ over India, Atmos. Pollut. Res., 10, 418-434, https://doi.org/10.1016/j.apr.2018.08.016, 2019.

Schaap, M., Apituley, A., Timmermans, R. M. A., Koelemeijer, R. B. A., and de Leeuw, G.: Exploring the relation between aerosol optical depth and $\mathrm{PM}_{2.5}$ at Cabauw, the Netherlands, Atmos. Chem. Phys., 9, 909-925, https://doi.org/10.5194/acp-9909-2009, 2009.

Schneider, P., Lahoz, W. A., and van der A, R.: Recent satellitebased trends of tropospheric nitrogen dioxide over large urban agglomerations worldwide, Atmos. Chem. Phys., 15, 12051220, https://doi.org/10.5194/acp-15-1205-2015, 2015.
Shaddick, G., Thomas, M. L., Amini, H., Broday, D., Cohen, A., Frostad, J., Green, A., Gumy, S., Liu, Y., Martin, R. V., Pruss-Ustun, A., Simpson, D., van Donkelaar, A., and Brauer, M.: Data Integration for the Assessment of Population Exposure to Ambient Air Pollution for Global Burden of Disease Assessment, Environ. Sci. Technol., 52, 9069-9078, https://doi.org/10.1021/acs.est.8b02864, 2018.

Shah, V., Jacob, D. J., Li, K., Silvern, R. F., Zhai, S., Liu, M., Lin, J., and Zhang, Q.: Effect of changing NOx lifetime on the seasonality and long-term trends of satellite-observed tropospheric $\mathrm{NO}_{2}$ columns over China, Atmos. Chem. Phys., 20, 1483-1495, https://doi.org/10.5194/acp-20-1483-2020, 2020.

Silvern, R. F., Jacob, D. J., Travis, K. R., Sherwen, T., Evans, M. J., Cohen, R. C., Laughner, J. L., Hall, S. R., Ullmann, K., Crounse, J. D., Wennberg, P. O., Peischl, J., and Pollack, I. B.: Observed $\mathrm{NO} / \mathrm{NO}_{2}$ Ratios in the Upper Troposphere Imply Errors in $\mathrm{NO}-\mathrm{NO}_{2}-\mathrm{O}_{3}$ Cycling Kinetics or an Unaccounted $\mathrm{NO}_{x}$ Reservoir, Geophys. Res. Lett., 45, 4466-4474, https://doi.org/10.1029/2018g1077728, 2018.

Silvern, R. F., Jacob, D. J., Mickley, L. J., Sulprizio, M. P., Travis, K. R., Marais, E. A., Cohen, R. C., Laughner, J. L., Choi, S., Joiner, J., and Lamsal, L. N.: Using satellite observations of tropospheric NO2 columns to infer long-term trends in US NOx emissions: the importance of accounting for the free tropospheric NO2 background, Atmos. Chem. Phys., 19, 8863-8878, https://doi.org/10.5194/acp-19-8863-2019, 2019.

Singh, R. B. and Grover, A.: Sustainable Urban Environment in Delhi Mega City: Emerging Problems and Prospects for Innovative Solutions, available at: https://sustainabledevelopment.un.org/content/documents/ 6494108_Singh\,\%20and\,\%20Grover_Sustainablel,\%20Urban\ ,\%20Environmentl,\%20in\,\%20Delhi.pdf (last access: 10 February 2021), 2015.

Singh, S. and Kulshrestha, U. C.: Abundance and distribution of gaseous ammonia and particulate ammonium at Delhi, India, Biogeosciences, 9, 5023-5029, https://doi.org/10.5194/bg9-5023-2012, 2012.

Snider, G., Weagle, C. L., Martin, R. V., van Donkelaar, A., Conrad, K., Cunningham, D., Gordon, C., Zwicker, M., Akoshile, C., Artaxo, P., Anh, N. X., Brook, J., Dong, J., Garland, R. M., Greenwald, R., Griffith, D., He, K., Holben, B. N., Kahn, R., Koren, I., Lagrosas, N., Lestari, P., Ma, Z., Vanderlei Martins, J., Quel, E. J., Rudich, Y., Salam, A., Tripathi, S. N., Yu, C., Zhang, Q., Zhang, Y., Brauer, M., Cohen, A., Gibson, M. D., and Liu, Y.: SPARTAN: a global network to evaluate and enhance satellite-based estimates of ground-level particulate matter for global health applications, Atmos. Meas. Tech., 8, 505-521, https://doi.org/10.5194/amt-8-505-2015, 2015.

Stieger, B., Spindler, G., Fahlbusch, B., Muller, K., Gruner, A., Poulain, L., Thoni, L., Seitler, E., Wallasch, M., and Herrmann, H.: Measurements of $\mathrm{PM}_{10}$ ions and trace gases with the online system MARGA at the research station Melpitz in Germany - A five-year study, J. Atmos. Chem., 75, 33-70, https://doi.org/10.1007/s10874-017-9361-0, 2018.

Streets, D. G., Canty, T., Carmichael, G. R., de Foy, B., Dickerson, R. R., Duncan, B. N., Edwards, D. P., Haynes, J. A., Henze, D. K., Houyoux, M. R., Jacobi, D. J., Krotkov, N. A., Lamsal, L. N., Liu, Y., Lu, Z. F., Martini, R. V., Pfister, G. G., Pinder, R. W., Salawitch, R. J., and Wechti, 
K. J.: Emissions estimation from satellite retrievals: A review of current capability, Atmos. Environ., 77, 1011-1042, https://doi.org/10.1016/j.atmosenv.2013.05.051, 2013.

Sugathan, A., Bhangale, R., Kansal, V., and Hulke, U.: How can Indian power plants cost-effectively meet the new sulfur emission standards? Policy evaluation using marginal abatement cost-curves, Energ. Policy, 121, 124-137, https://doi.org/10.1016/j.enpol.2018.06.008, 2018.

Surl, L., Palmer, P. I., and González Abad, G.: Which processes drive observed variations of HCHO columns over India?, Atmos. Chem. Phys., 18, 4549-4566, https://doi.org/10.5194/acp18-4549-2018, 2018.

Tang, Y. S., Braban, C. F., Dragosits, U., Dore, A. J., Simmons, I., van Dijk, N., Poskitt, J., Dos Santos Pereira, G., Keenan, P. O., Conolly, C., Vincent, K., Smith, R. I., Heal, M. R., and Sutton, M. A.: Drivers for spatial, temporal and long-term trends in atmospheric ammonia and ammonium in the UK, Atmos. Chem. Phys., 18, 705-733, https://doi.org/10.5194/acp-18-7052018, 2018.

Theys, N., Hedelt, P., De Smedt, I., Lerot, C., Yu, H., Vlietinck, J., Pedergnana, M., Arellano, S., Galle, B., Fernandez, D., Carlito, C. J. M., Barrington, C., Taisne, B., Delgado-Granados, H., Loyola, D., and Van Roozendael, M.: Global monitoring of volcanic $\mathrm{SO}_{2}$ degassing with unprecedented resolution from TROPOMI onboard Sentinel-5 Precursor, Sci. Rep.-UK, 9, 2643, https://doi.org/10.1038/s41598-019-39279-y, 2019.

ul-Haq, Z., Tariq, S., and Ali, M.: Tropospheric $\mathrm{NO}_{2}$ Trends over South Asia during the Last Decade (2004-2014) Using OMI Data, Adv. Meteorol., https://doi.org/10.1155/2015/959284, 2015.

UN: Department of Economic and Social Affairs - Population Division, New York, World Urbanization Prospects: The 2018 Revision, available at: https://population.un.org/wup/Publications/ Files/WUP2018-Report.pdf (last access: 8 February 2021), 2019.

Université libre de Bruxelles (ULB): IASI NH3 data, available at: https://iasi.aeris-data.fr/nh3/, last access: 8 March 2021.

Valach, A. C., Langford, B., Nemitz, E., MacKenzie, A. R., and Hewitt, C. N., Concentrations of selected volatile organic compounds at kerbside and background sites in central London, Atmos. Environ., 95, 456-467, https://doi.org/10.1016/j.atmosenv.2014.06.052, 2014.

Van Damme, M., Clarisse, L., Heald, C. L., Hurtmans, D., Ngadi, Y., Clerbaux, C., Dolman, A. J., Erisman, J. W., and Coheur, P. F.: Global distributions, time series and error characterization of atmospheric ammonia (NH3) from IASI satellite observations, Atmos. Chem. Phys., 14, 2905-2922, https://doi.org/10.5194/acp14-2905-2014, 2014.

Van Damme, M., Clarisse, L., Dammers, E., Liu, X., Nowak, J. B., Clerbaux, C., Flechard, C. R., Galy-Lacaux, C., Xu, W., Neuman, J. A., Tang, Y. S., Sutton, M. A., Erisman, J. W., and Coheur, P. F.: Towards validation of ammonia (NH3) measurements from the IASI satellite, Atmos. Meas. Tech., 8, 15751591, https://doi.org/10.5194/amt-8-1575-2015, 2015.

Van Damme, M., Whitburn, S., Clarisse, L., Clerbaux, C., Hurtmans, D., and Coheur, P.-F.: Version 2 of the IASI $\mathrm{NH}_{3}$ neural network retrieval algorithm: near-real-time and reanalysed datasets, Atmos. Meas. Tech., 10, 4905-4914, https://doi.org/10.5194/amt-10-4905-2017, 2017.
Van Damme, M., Clarisse, L., Whitburn, S., Hadji-Lazaro, J., Hurtmans, D., Clerbaux, C., and Coheur, P. F.: Industrial and agricultural ammonia point sources exposed, Nature, 564, 99-110, https://doi.org/10.1038/s41586-018-0747-1, 2018.

Van Damme, M., Clarisse, L., Franco, B., Sutton, M. A., Erisman, J. W., Kruit, R. J. W., van Zanten, M., Whitburn, S., HadjiLazaro, J., Hurtmans, D., Clerbaux, C., and Coheur, P. F.: Global, regional and national trends of atmospheric ammonia derived from a decadal (2008-2018) satellite record, Environ. Res. Lett., https://doi.org/10.1088/1748-9326/abd5e0, in press, 2020.

van der A, R. J., Peters, D. H. M. U., Eskes, H., Boersma, K. F., Van Roozendael, M., De Smedt, I., and Kelder, H. M.: Detection of the trend and seasonal variation in tropospheric $\mathrm{NO}_{2}$ over China, J. Geophys. Res.-Atmos., 111, D12317, https://doi.org/10.1029/2005jd006594, 2006.

van der A, R. J., Eskes, H. J., Boersma, K. F., van Noije, T. P. C., Van Roozendael, M., De Smedt, I., Peters, D. H. M. U., and Meijer, E. W.: Trends, seasonal variability and dominant $\mathrm{NO}_{x}$ source derived from a ten year record of $\mathrm{NO}_{2}$ measured from space, J. Geophys. Res.-Atmos., 113, D04302, https://doi.org/10.1029/2007jd009021, 2008.

van Donkelaar, A., Martin, R. V., and Park, R. J.: Estimating ground-level $\mathrm{PM}_{2.5}$ using aerosol optical depth determined from satellite remote sensing, J. Geophys. Res.-Atmos., 111, D21201, https://doi.org/10.1029/2005jd006996, 2006.

van Donkelaar, A., Martin, R. V., Brauer, M., Kahn, R., Levy, R., Verduzco, C., and Villeneuve, P. J.: Global Estimates of Ambient Fine Particulate Matter Concentrations from Satellite-Based Aerosol Optical Depth: Development and Application, Environ. Health Persp., 118, 847-855, https://doi.org/10.1289/ehp.0901623, 2010.

van Donkelaar, A., Martin, R. V., Brauer, M., Hsu, N. C., Kahn, R. A., Levy, R. C., Lyapustin, A., Sayer, A. M., and Winker, D. M.: Global Estimates of Fine Particulate Matter using a Combined Geophysical-Statistical Method with Information from Satellites, Models, and Monitors, Environ. Sci. Technol., 50, 3762-3772, https://doi.org/10.1021/acs.est.5b05833, 2016.

Vasilkov, A., Krotkov, N., Yang, E.-S., Lamsal, L., Joiner, J., Castellanos, P., Fasnacht, Z., and Spurr, R.: Explicit and consistent aerosol correction for visible wavelength satellite cloud and nitrogen dioxide retrievals based on optical properties from a global aerosol analysis, Atmos. Meas. Tech. Discuss. [preprint], https://doi.org/10.5194/amt-2019-458, in review, 2020.

Venkataraman, C., Brauer, M., Tibrewal, K., Sadavarte, P., Ma, Q., Cohen, A., Chaliyakunnel, S., Frostad, J., Klimont, Z., Martin, R. V., Millet, D. B., Philip, S., Walker, K., and Wang, S.: Source influence on emission pathways and ambient $\mathrm{PM}_{2.5}$ pollution over India (2015-2050), Atmos. Chem. Phys., 18, 8017-8039, https://doi.org/10.5194/acp-18-8017-2018, 2018.

Vieno, M., Heal, M. R., Hallsworth, S., Famulari, D., Doherty, R. M., Dore, A. J., Tang, Y. S., Braban, C. F., Leaver, D., Sutton, M. A., and Reis, S.: The role of long-range transport and domestic emissions in determining atmospheric secondary inorganic particle concentrations across the UK, Atmos. Chem. Phys., 14, 8435-8447, https://doi.org/10.5194/acp-14-8435-2014, 2014.

Vieno, M., Heal, M. R., Williams, M. L., Carnell, E. J., Nemitz, E., Stedman, J. R., and Reis, S.: The sensitivities of emissions reductions for the mitigation of $\mathrm{UK} \mathrm{PM}_{2.5}$, Atmos. Chem. Phys., 16, 265-276, https://doi.org/10.5194/acp-16-265-2016, 2016. 
Vodonos, A., Abu Awad, Y., and Schwartz, J.: The concentrationresponse between long-term $\mathrm{PM}_{2.5}$ exposure and mortality; A meta-regression approach, Environ. Res., 166, 677-689, https://doi.org/10.1016/j.envres.2018.06.021, 2018.

Vohra, K.: India NO2 data, Zenodo [Data set], https://doi.org/10.5281/zenodo.4696252, 2021.

Vohra, K., Vodonos, A., Schwartz, J., Marais, E. A., Sulprizio, M. P., and Mickley, L. J.: Global mortality from outdoor fine particle pollution generated by fossil fuel combustion: Results from GEOS-Chem, Environ. Res., 195, 110754, https://doi.org/10.1016/j.envres.2021.110754, 2021.

Walker, H. L., Heal, M. R., Braban, C. F., Ritchie, S., Conolly, C., Sanocka, A., Dragosits, U., and Twigg, M. M.: Changing supersites: assessing the impact of the southern UK EMEP supersite relocation on measured atmospheric composition, Environ. Res. Comm., 1, 041001, https://doi.org/10.1088/2515-7620/ab1a6f, 2019.

Wang, L., Slowik, J. G., Tripathi, N., Bhattu, D., Rai, P., Kumar, V., Vats, P., Satish, R., Baltensperger, U., Ganguly, D., Rastogi, N., Sahu, L. K., Tripathi, S. N., and Prévôt, A. S. H.: Source characterization of volatile organic compounds measured by proton-transfer-reaction time-of-flight mass spectrometers in Delhi, India, Atmos. Chem. Phys., 20, 9753-9770, https://doi.org/10.5194/acp-20-9753-2020, 2020.

Wang, T., Song, Y., Xu, Z., Liu, M., Xu, T., Liao, W., Yin, L., Cai, X., Kang, L., Zhang, H., and Zhu, T.: Why is the Indo-Gangetic Plain the region with the largest $\mathrm{NH}_{3}$ column in the globe during pre-monsoon and monsoon seasons?, Atmos. Chem. Phys., 20, 8727-8736, https://doi.org/10.5194/acp-20-8727-2020, 2020.

Warner, J. X., Dickerson, R. R., Wei, Z., Strow, L. L., Wang, Y., and Liang, Q.: Increased atmospheric ammonia over the world's major agricultural areas detected from space, Geophys. Res. Lett., 44, 2875-2884, https://doi.org/10.1002/2016g1072305, 2017.

Weagle, C. L., Snider, G., Li, C., van Donkelaar, A., Philip, S., Bissonnette, P., Burke, I., Jackson, J., Latimer, R., Stone, E., Abboud, I., Akoshile, C., Anh, N. X., Brook, J. R., Cohen, A., Dong, J. L., Gibson, M. D., Griffith, D., He, K. B., Holben, B. N., Kahn, R., Keller, C. A., Kim, J. S., Lagrosas, N., Lestari, P., Khian, Y. L., Liu, Y., Marais, E. A., Martins, J. V., Misra, A., Muliane, U., Pratiwi, R., Quel, E. J., Salam, A., Segey, L., Tripathi, S. N., Wang, C., Zhang, Q., Brauer, M., Rudich, Y., and Martin, R. V.: Global Sources of Fine Particulate Matter: Interpretation of $\mathrm{PM}_{2.5}$ Chemical Composition Observed by SPARTAN using a Global Chemical Transport Model, Environ. Sci. Technol., 52, 11670-11681, https://doi.org/10.1021/acs.est.8b01658, 2018.

Weatherhead, E. C., Reinsel, G. C., Tiao, G. C., Meng, X. L., Choi, D. S., Cheang, W. K., Keller, T., DeLuisi, J., Wuebbles, D. J., Kerr, J. B., Miller, A. J., Oltmans, S. J., and Frederick, J. E.: Factors affecting the detection of trends: Statistical considerations and applications to environmental data, J. Geophys. Res.-Atmos., 103, 17149-17161, https://doi.org/10.1029/98jd00995, 1998.

Wei, J., Sun, L., Peng, Y. R., Wang, L. C., Zhang, Z. Y., Bilal, M., and Ma, Y. C.: An Improved High-SpatialResolution Aerosol Retrieval Algorithm for MODIS Images Over Land, J. Geophys. Res.-Atmos., 123, 12291-12307, https://doi.org/10.1029/2017jd027795, 2018.

Wei, J., Li, Z. Q., Peng, Y. R., and Sun, L.: MODIS Collection 6.1 aerosol optical depth products over land and ocean: validation and comparison, Atmos. Environ., 201, 428-440, https://doi.org/10.1016/j.atmosenv.2018.12.004, 2019.

Wei, J., Li, Z. Q., Sun, L., Peng, Y. R., Liu, L., He, L. J., Qin, W. M., and Cribb, M.: MODIS Collection 6.1 $3 \mathrm{~km}$ resolution aerosol optical depth product: global evaluation and uncertainty analysis, Atmos. Environ., 240, 117768, 10.1016/j.atmosenv.2020.117768, 2020.

Whalley, L. K., Stone, D., Bandy, B., Dunmore, R., Hamilton, J. F., Hopkins, J., Lee, J. D., Lewis, A. C., and Heard, D. E.: Atmospheric $\mathrm{OH}$ reactivity in central London: observations, model predictions and estimates of in situ ozone production, Atmos. Chem. Phys., 16, 2109-2122, https://doi.org/10.5194/acp16-2109-2016, 2016.

Whalley, L. K., Stone, D., Dunmore, R., Hamilton, J., Hopkins, J. R., Lee, J. D., Lewis, A. C., Williams, P., Kleffmann, J., Laufs, S., Woodward-Massey, R., and Heard, D. E.: Understanding in situ ozone production in the summertime through radical observations and modelling studies during the Clean air for London project (ClearfLo), Atmos. Chem. Phys., 18, 2547-2571, https://doi.org/10.5194/acp-18-2547-2018, 2018.

Whitburn, S., Van Damme, M., Clarisse, L., Bauduin, S., Heald, C. L., Hadji-Lazaro, J., Hurtmans, D., Zondlo, M. A., Clerbaux, C., and Coheur, P. F.: A flexible and robust neural network IASI$\mathrm{NH}_{3}$ retrieval algorithm, J. Geophys. Res.-Atmos., 121, 65816599, https://doi.org/10.1002/2016jd024828, 2016.

WHO; World Health Organization, WHO Global Urban Ambient Air Pollution Database, available at: https://www.who.int/phe/ health_topics/outdoorair/databases/cities/en/ (last access: 16 January 2020), 2018.

World Bank, Leveraging Spatial Development Options for Uttar Pradesh, available at: http://documents1. worldbank.org/curated/en/751141468269412833/pdf/ 889670WP0URGEN00Box385254B00PUBLIC0.pdf (last access: 8 March 2021), 2014.

Yadav, R., Sahu, L. K., Beig, G., Tripathi, N., and Jaaffrey, S. N. A.: Ambient particulate matter and carbon monoxide at an urban site of India: Influence of anthropogenic emissions and dust storms, Environ. Pollut., 225, 291-303, https://doi.org/10.1016/j.envpol.2017.01.038, 2017.

Zara, M., Boersma, K. F., De Smedt, I., Richter, A., Peters, E., van Geffen, J. H. G. M., Beirle, S., Wagner, T., Van Roozendael, M., Marchenko, S., Lamsal, L. N., and Eskes, H. J.: Improved slant column density retrieval of nitrogen dioxide and formaldehyde for OMI and GOME-2A from QA4ECV: intercomparison, uncertainty characterisation, and trends, Atmos. Meas. Tech., 11, 4033-4058, https://doi.org/10.5194/amt-11-4033-2018, 2018.

Zara, M., Boersma, F., Eskes, H., van der Gon, H. D., de Arellano, J. V.-G., Krol, M., van der Swaluw, E., Schuch, W., and Velders, G. J. M.: Reductions in nitrogen oxides over the Netherlands between 2005 and 2018 observed from space and on the ground: Decreasing emissions and increasing $\mathrm{O}_{3}$ indicate changing $\mathrm{NO}_{x}$ chemistry, Atmos. Environ., 9, 100104, https://doi.org/10.1016/j.aeaoa.2021.100104, 2021.

Zhu, L., Jacob, D. J., Mickley, L. J., Marais, E. A., Cohan, D. S., Yoshida, Y., Duncan, B. N., Abad, G. G., and Chance, K. V.: Anthropogenic emissions of highly reactive volatile organic compounds in eastern Texas inferred from oversampling of satellite (OMI) measurements of HCHO columns, Environ. Res. Lett., 9 114004, https://doi.org/10.1088/1748-9326/9/11/114004, 2014. 
Zhu, L., Jacob, D. J., Kim, P. S., Fisher, J. A., Yu, K., Travis, K. R., Mickley, L. J., Yantosca, R. M., Sulprizio, M. P., De Smedt, I., González Abad, G., Chance, K., Li, C., Ferrare, R., Fried, A., Hair, J. W., Hanisco, T. F., Richter, D., Jo Scarino, A., Walega, J., Weibring, P., and Wolfe, G. M.: Observing atmospheric formaldehyde ( $\mathrm{HCHO}$ ) from space: validation and intercomparison of six retrievals from four satellites (OMI, GOME2A, GOME2B, OMPS) with SEAC ${ }^{4}$ RS aircraft observations over the southeast US, Atmos. Chem. Phys., 16, 1347713490, https://doi.org/10.5194/acp-16-13477-2016, 2016.
Zoogman, P., Jacob, D. J., Chance, K., Zhang, L., Le Sager, P., Fiore, A. M., Eldering, A., Liu, X., Natraj, V., and Kulawik, S. S.: Ozone air quality measurement requirements for a geostationary satellite mission, Atmos. Environ., 45, 7143-7150, https://doi.org/10.1016/j.atmosenv.2011.05.058, 2011. 